OPEN ACCESS

Edited by:

Guo Donglin,

Zhan Kezhen-Nansen International

Research Center, Institute of Atmospheric Physics (CAS), China

Reviewed by:

Xiaoging Peng,

Lanzhou University, China

Wansheng Pei,

Northwest Institute of ECO-

Environment and Resources (CAS),

China

Xicai Pan,

Institute of Soil Science (CAS), China

*Correspondence:

Yan Li

liyan1@nieer.ac.cn

Huijun Jin

hijii@nefu.edu.cn

Specialty section: This article was submitted to

Cryospheric Sciences,

a section of the journal

Frontiers in Earth Science

Received: 31 October 2021 Accepted: 04 January 2022

Published: 25 January 2022

Citation:

He R, Li Y, Jin H, Wang H, Jin X, Zhu M, Li X, Huang Y, Jin D and Ma F (2022)

Thermal Recovery of Backfilled Pit in the Gulianhe Strip Coalmine in the Hola

Basin in Northern Da Xing'Anling Mountains, NE China.

Front. Earth Sci. 10:806022. doi: 10.3389/feart.2022.806022

\section{Thermal Recovery of Backfilled Pit in the Gulianhe Strip Coalmine in the Hola Basin in Northern Da Xing'Anling Mountains, NE China}

\author{
Ruixia He ${ }^{1}$, Yan $\mathrm{Li}^{1,2 *}$, Huijun $\mathrm{Jin}^{1,2,3 *}$, Hongwei Wang ${ }^{1}$, Xiaoying $\mathrm{Jin}^{3}$, Meiquan $\mathrm{Zhu}^{3}$, \\ Xinyu $\mathrm{Li}^{4}$, Yadong Huang ${ }^{1,2}$, Doudou $\mathrm{Jin}^{1,2}$ and Futing $\mathrm{Ma}^{5}$

\begin{abstract}
'State Key Laboratory of Frozen Soils Engineering, Da Xing'anling Observation and Research Station of Frozen-Ground Engineering and Environment, Northwest Institute of Eco-Environment and Resources, Chinese Academy of Sciences, Lanzhou, China, ${ }^{2}$ School of Resources and Environment, University of Chinese Academy of Sciences, Beijing, China, ${ }^{3}$ School of Civil Engineering, Institute of Cold Regions Science and Engineering, Northeast-China Observatory and Research-Station of Permafrost Geo-Environment (Ministry of Education), Northeast Forest University, Harbin, China, ${ }^{4}$ School of Civil Engineering, Harbin Institute of Technology, Harbin, China, ${ }^{5}$ Gulianhe Strip Coalmine, Heilongjiang, China
\end{abstract}

In the northern Da Xing'anling Mountains in Northeast China on the southern margin of the Eastern Asia permafrost body, the ground thermal state and boreal ecological environment are sensitive to climate change and human activities. Since the 1980s, the Hola Basin here has been continuously and extensively developed. In particular, open pits and later backfilling in strip coal mining alters land-atmospheric hydrothermal exchanges in permafrost regions, leading to serious damages to the permafrost environment and boreal forest. After mining, pits need to be backfilled timely and properly for hydrothermal recovery of Xing'an permafrost and the boreal ecological environment. In this study, based on the comparative analysis of monitored ground temperatures in backfilled and undisturbed areas, influencing factors of thermal recovery after backfilling were analyzed through numerical simulations. Results show that the thermal recovery of permafrost in the backfilled area is closely related to temperature, depth, material, and soil moisture content of backfill. The warmer, finer, and thicker the backfill soils, the longer the permafrost recovery. Thermal recovery of permafrost also depends on the moisture content of backfill; the shortest recovery occurs at $15-25 \%$ in the backfilled soil moisture content. Based on numerical simulations and combined with enlightenments from features of the ecosystem-protected Xing'an permafrost in Northeast China, a composite configuration of organic soil, crush-rock layer, and proper re-vegetation measures is advised. Based on prudent regulation of heat transfer modes, this composite backfilling method can effectively cool the backfilled ground and can even possibly offset the climate warming.

Keywords: strip coalmine, Xing'an permafrost, open-pit, backfilling, thermal recovery, influencing factor 


\section{INTRODUCTION}

Coal is one of the important pillar industries in most northern countries. With the exploitation and transportation of coal resources, some problems of environmental pollution and ecological damage have become increasingly prominent and widely concerned, with serious impacts on the sustainable development of coalmine enterprises and the ecological environment (e.g., Bell et al., 2001; Pandey et al., 2014; Qian et al., 2017). Because of the harsh climate and fragile ecological environment in cold regions, mining activities will consequently alter hydrothermal exchanges and transport processes between the ground and atmosphere, resulting in adverse impacts to the hydrothermal stability of permafrost and a long-established ecological environment (e.g., Ding, 1988; Burov and Gresov, 2011; Cao et al., 2011; Demirel et al., 2011; James et al., 2013; Gao et al., 2017). In particular, strip coal mining disrupts, damages, or even destroys pristine boreal forests, original landforms, and intact surfaces, eventually resulting in land degradation and soil erosion, with mine pits reaching tens or even hundreds of meters in depth and leading to permafrost thinning or thaw; in the areas underlain by cold and thick permafrost, waters from melting ground ice, surface snowmelt and runoff, and precipitation gather at the bottom of mine pits, accelerating permafrost thaw (Zheng et al., 2000; Cao and Sheng, 2013; Li et al., 2014). At the same time, exposed cut slopes formed by strip mining are prone to collapse or landslides due to the thawing permafrost, and saturated gangue piles/hills are also prone to slumps, gelifluctions, debris flows, or mudflows (e.g., Hildebrand 1983; Peretrukhin and Potaueva 1983; Zheng et al., 2000; Jin et al., 2008; Cao and Sheng, 2013; Nauta et al., 2014; Zhang M. et al., 2015; Zhang et al., 2017; Booshehrian et al., 2020). In addition, the permafrost table was locally lowered due to the mining excavation, and the water-retaining properties of the permafrost layer will be dramatically weakened or totally lost; the water table may be lowered substantially and rapidly, and it becomes too deep for water availability for plant growth, leading to the succession of the biological community and the ecological environment (Wang et al., 2004; Quinton et al., 2005; Cao et al., 2011; Quinton and Baltzer, 2013; Gao et al., 2017). Therefore, it is important to protect the natural environment in the processes of coal resource exploitation and to propose reasonable, economical, and effective measures for solving engineering problems in the mining area. At present, pit backfilling is the most effective and economical method for land reclamation after coal mining. It not only reduces geohazard risks and protects the environment but also helps recover surface vegetation after land reclamation (e.g., Moreno-de Las Heras et al., 2009; Erener, 2011; Zhang L. et al., 2015; Wang et al., 2016, 2021a, 2021b). Timely and proper backfilling might also benefit the recovery of ground temperature and the permafrost environment. However, existing research mainly focuses on the influences of the topography and backfill properties of strip coalmines on the re-vegetation in permafrost areas. Only few research works are carried out on the evaluation methods of the permafrost environment and numerical simulations of the impacts of excavation backfilling on the permafrost recovery in strip coal mines. Because of paucity of field monitoring data, the influencing mechanisms for and factors on ground temperature recovery in backfill areas have not yet been studied systematically (e.g., Li et al., 2014; Cao et al., 2016; Gao et al., 2017). In summary, inadequate attention has been paid on thermal recovery processes after backfilling in permafrost regions and their influencing mechanisms and factors. In particular, key influencing factors for the thermal recovery of backfilled soils, such as backfill materials and their properties, are seldom mentioned.

The Gulianhe strip coalmine in the Hola Basin is in the discontinuous permafrost zone in the northern Da Xing'anling Mountains in Northeast China. The region is characterized by extensive and stable winter air temperature inversion, thick surficial deposits, dense vegetation, stable snow cover, and extensive distribution of intermontane wetlands. In the discontinuous permafrost zone in the north, permafrost generally forms in the low-lying and north-facing landscape conditions, and is protected by ecosystems; its distribution displays strong spatial variations. It is thus the ecosystemprotected permafrost (Shur and Jorgenson, 2007). Therefore, this ecosystem-protected permafrost in the northern part of Northeast China is generally referred to as the "Xing'an permafrost" for its distinct developing and the growth environment in boreal forests and wetlands (Zhou et al., 2000; Jin et al., 2008). In comparison with the permafrost on the Qinghai-Tibet Plateau, the Xing'an permafrost are less sensitive to climate changes, but they are more responsive to human activities or other external disturbances that may modify or alter surface covers and drainage conditions (e.g., mining and transportation, land cultivation and reclamation, deforestation, urbanization, and forest fires).

The Gulianhe coalmine has been adopting the strip-mining techniques since it was put into production in 1992. During the mining process, the seasonally thawed layer over permafrost (active layer) was stripped in advance and the permafrost soil was thawed at first, followed by downward digging/stripping layer by layer. Mining activities in combination with the overburden and rock dumping/disposal greatly damaged or destroyed the original natural surface and vegetation cover, leading to damages to the vulnerable permafrost environment and delicate ecological balance of boreal forest. Now, there are dozens of pits in the mining areas in the Hola Basin. These open pits are generally $60,000-100,000 \mathrm{~m}^{2}$ in areal extent and $25-40 \mathrm{~m}$ in depth. Extensive engineering infrastructures, such as open pits, gangue piles, waste banks, and access/trucking roads, have become major drivers for an accelerated degradation of Xing'an permafrost in the Hola Basin (Serban et al., 2021). Evidently, timely restoration of the permafrost environment and maintenance of the local balance of boreal ecology for sustainable development of mining areas are generally mandated, and the hydrothermal responses of the backfilled open pits in frozen ground are worth systematic and in-depth studying. However, due to the chronic thermal recovery of permafrost, studies on changes in ground temperature require long-term monitoring data. Thus, numerical simulations and field monitoring can be combined to analyze the recovery processes of permafrost and their influencing factors. 

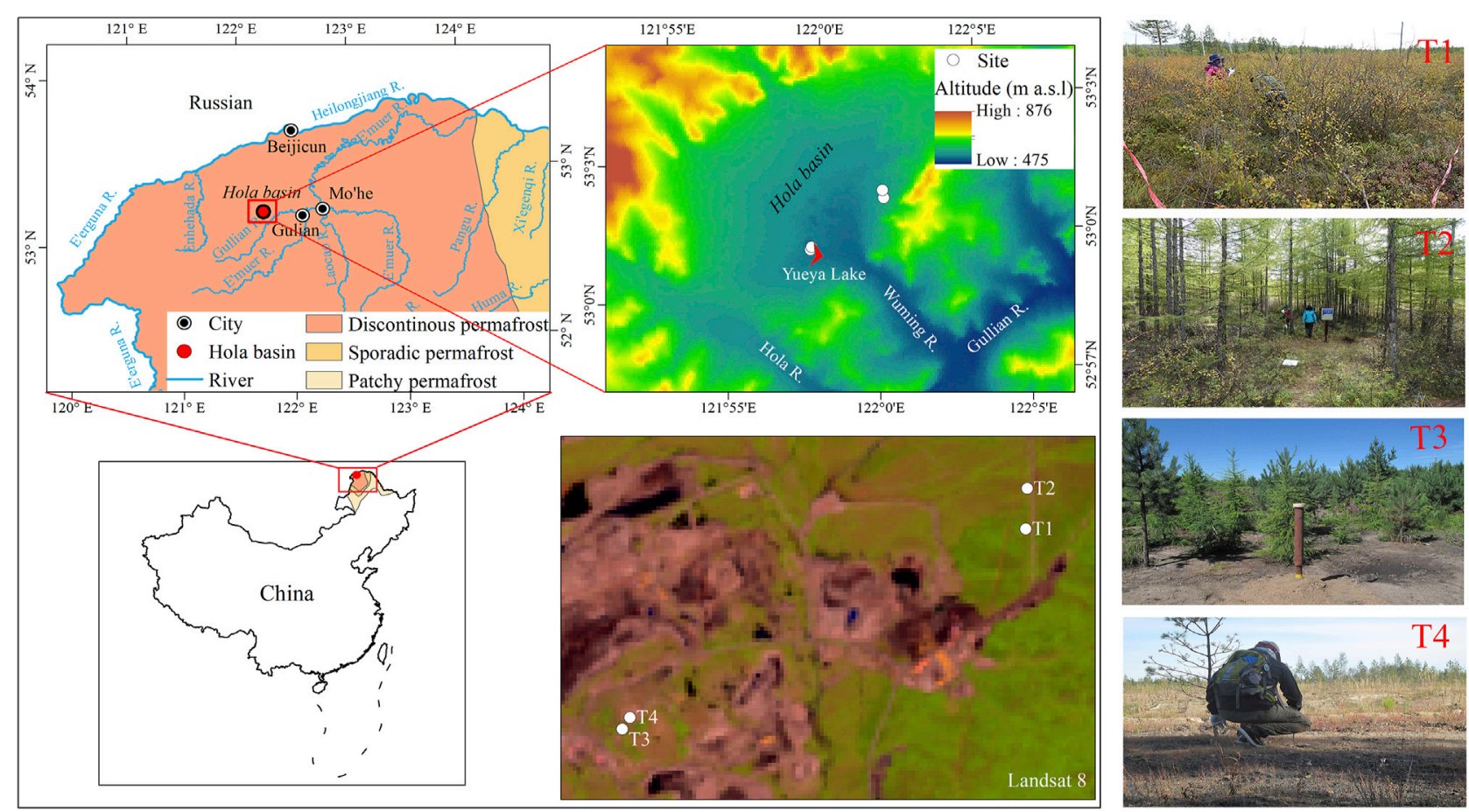

FIGURE 1 | Study region and sites in the Gulianhe Strip coalmine in the Hola Basin in the northern Da Xing'anling Mountains in Northeast China.

In our study, first, two representative backfilled and undisturbed areas were selected for monitoring ground temperatures. Then a numerical model for heat transfer in permafrost regions was established for studying the influencing factors of heat transfer. Finally, through the comparisons of simulated and monitored data of backfill temperature, ground temperatures during backfilling and the backfilling time, we identified the major influencing factors for ground temperature recovery. The study can provide key scientific support for environmental protection and ecological restoration of open pit coalmines in the boreal forest in permafrost zones.

\section{MATERIALS AND METHODS}

\subsection{Study Area}

As a representative intermontane basin at relatively high latitudes in the northern $\mathrm{Da}$ Xing'anling Mountains, the Hola Basin $\left(52^{\circ} 57^{\prime}-53^{\circ} 03^{\prime} \mathrm{N}, 121^{\circ} 52^{\prime}-122^{\circ} 04^{\prime} \mathrm{E}\right.$ ) (Figure 1) is encircled by forested low hills, with an areal extent of about $60 \mathrm{~km}^{2}$, and the peripheral mountains of the Hola Basin, about $130 \mathrm{~km}^{2}$. The fault-depressed Hola Basin is high in the north, sloping gently southward.

The study area has a cold, continental climate in the northern temperate zone. Due to strong influences of alternating monsoons, regional climate is characterized by long, dry, and cold winters and short, moist, and warm summers, without distinct spring and autumn seasons. According to the data from the Mo'he meteorological station (196,1-2020), the mean annual air temperature (MAAT) was $-4.1^{\circ} \mathrm{C}$; the recorded minimum and maximum air temperatures reached at $-46.7^{\circ} \mathrm{C}$ (December 27,1968 ) and $28.1^{\circ} \mathrm{C}$ (June 27,2010 ), respectively. MAAT was warming at a rate of about $0.035^{\circ} \mathrm{C} / \mathrm{a}$ during 1961-2020. The average annual precipitation was $440 \mathrm{~mm}$.

Before the 1980s, the measured permafrost thickness at the bottom (center) of the Hola Basin was 70-100 m (the maximum at $130 \mathrm{~m}$ ) and that in the periphery transition zone was $40-50 \mathrm{~m}$; it was finally thinned to $10-20 \mathrm{~m}$ at the slope toes of surrounding hills. Ground temperature at the depth of zero annual amplitude $\left(\mathrm{T}_{\mathrm{ZAA}}\right)$ increased from $-3.5 \sim-3.0 \mathrm{C}$ at the center to $-0.5^{\circ} \mathrm{C}$ on the margin of the basin. Taliks were mainly distributed on the tops of low hills and gentle sunny slope toes around the Hola Basin (Guo et al., 1989; Wang et al., 1989; He et al., 2015). Prior to the 1980s, the Hola Basin was a pristine boreal forest dominated by Xing'an larch (Larix gmelinii) and Scotch pine (Pinus sylvestris). The mixed broadleaf-conifer forest extends from the gentle slope toes to the bottom of the basin. The main tree species were Xing'an larch (Larix gmelinii), Asian white birch (Betula platyphylla), and Scotch pine (Pinus sylvestris), and the undergrowth, Vaccinium uliginosum Linn. and Betula fruticose Pallas. Carex tato wetlands and shrub-Carex tato wetlands were extensively developed on the bottom of the basin.

The large-scale resource exploitations in the Hola Basin, especially the strip coal mining since the 1990s, have severely disturbed the local ecological environment. Field investigations have found great changes in the surrounding permafrost environment in comparison with that before mining (Serban 
TABLE 1 | Detailed information of four boreholes for ground temperature measurements at the backfilled and undisturbed areas in the Gulianhe strip coalmine in the Hola Basin in the northern Da Xing'anling Mountains in Northeast China.

\begin{tabular}{|c|c|c|c|c|}
\hline Borehole & T1 & T2 & T3 & T4 \\
\hline Latitude $\left({ }^{\circ} \mathrm{N}\right)$ & $53^{\circ} 00.889^{\prime}$ & $53^{\circ} 00.989^{\prime}$ & $53^{\circ} 00.463^{\prime}$ & $53^{\circ} 00.511^{\prime}$ \\
\hline Longitude ('E) & $122^{\circ} 00.951^{\prime}$ & $122^{\circ} 00.928^{\prime}$ & $121^{\circ} 58.521^{\prime}$ & $121^{\circ} 58.574^{\prime}$ \\
\hline Elevation(m a. s. I.) & 535 & 532 & 522 & 523 \\
\hline Monitoring depth (m) & 20 & 20 & 20 & 20 \\
\hline Backfill depth (m) & - & - & 2.6 & 20 \\
\hline Backfill material & - & - & Gravel & Coal gangue/slag \\
\hline Surface characteristics & Carex tato and shrubs & Larix gmelinii & Planted Larix gmelinii & Bare ground \\
\hline Time period & $2017-2020$ & 2017-2020 & $2015-2020$ & 2015-2020 \\
\hline
\end{tabular}

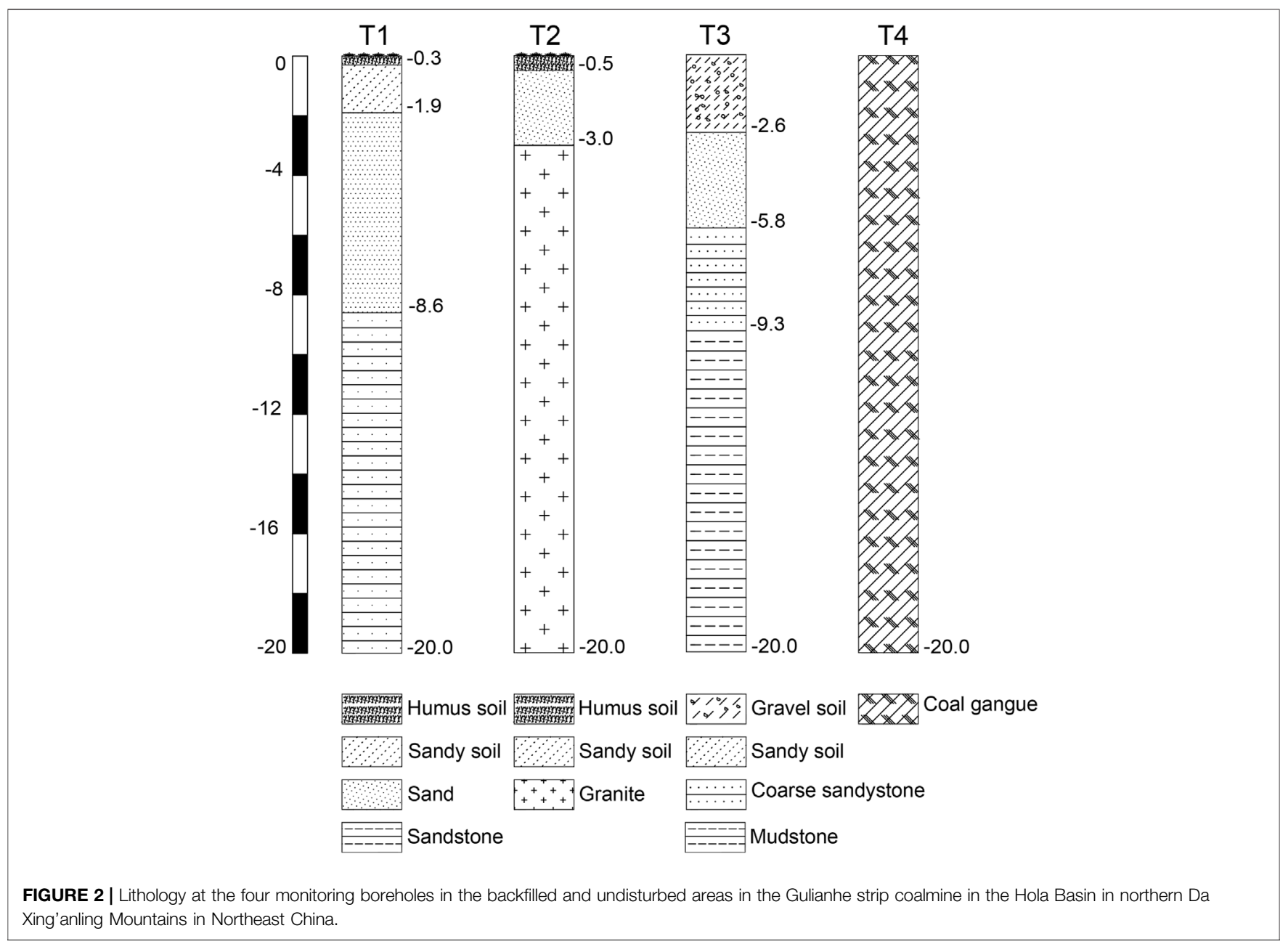

et al., 2021). To facilitate the mandated ecological recovery, some open pits were backfilled in 2007.

\subsection{Data Monitoring}

\subsubsection{Site Descriptions and Measurements}

Two areas (undisturbed and backfilled) (Figure 1) in the Hola Basin were selected to study the influences of pit backfilling in strip coalmines on permafrost recovery. A pristine forestland with minor anthropogenic disturbances in the northern Hola Basin was chosen as the undisturbed area. Two ground temperature boreholes of $20.0 \mathrm{~m}$ in depth (Figure 1) were established in shrub-Carex tato wetland (T1) and Larix gmelinii (T2) forest at this undisturbed area in September 2017. In mining areas, some excavated pits were backfilled in summer and autumn 2007 for ecological restoration. The other two boreholes (T3 and T4, both $20.0 \mathrm{~m}$ in depth) (Figure 1) were established in the backfilled area in August 2014. Borehole T3 was established at the experimental forest plot of Northeast Forestry University, with a 2.6-m thick backfill covered by a dry ground surface re-planted with Larix gmelinii and Betula platyphylla. 
A

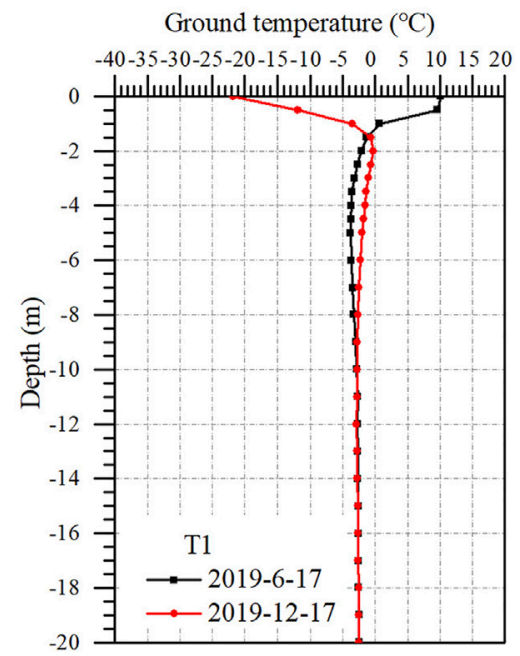

B Ground temperature $\left({ }^{\circ} \mathrm{C}\right)$

B $\quad-40-35-30-25-20-15-10-5 \quad 0 \quad 5 \quad 101520$

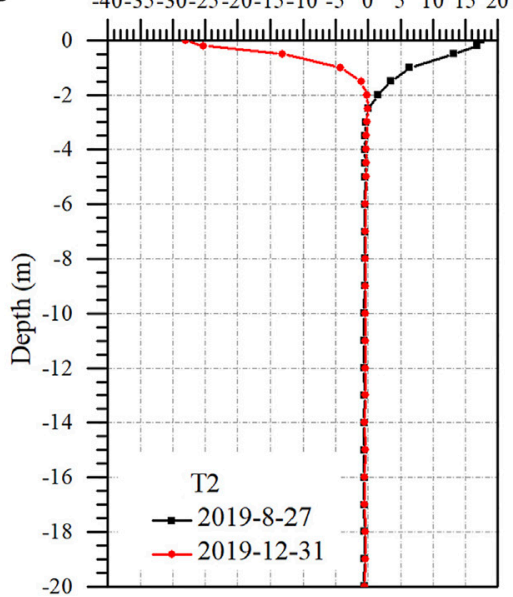

$-20$

Ground temperature $\left({ }^{\circ} \mathrm{C}\right)$

D $\quad \begin{array}{rrrrrrrrrr}-10 & -8 & -6 & -4 & -2 & 0 & 2 & 4 & 6\end{array}$

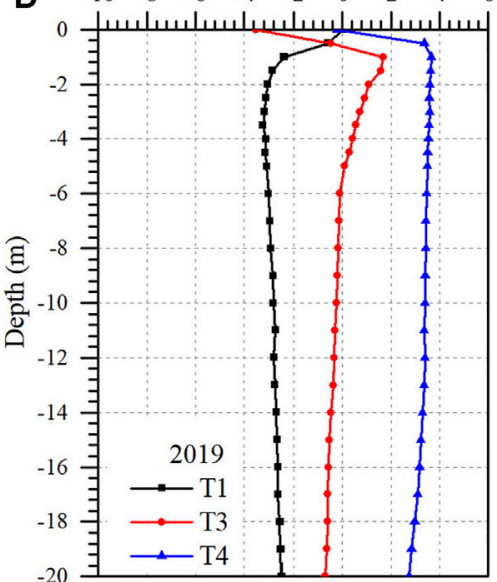

Ground temperature $\left({ }^{\circ} \mathrm{C}\right)$

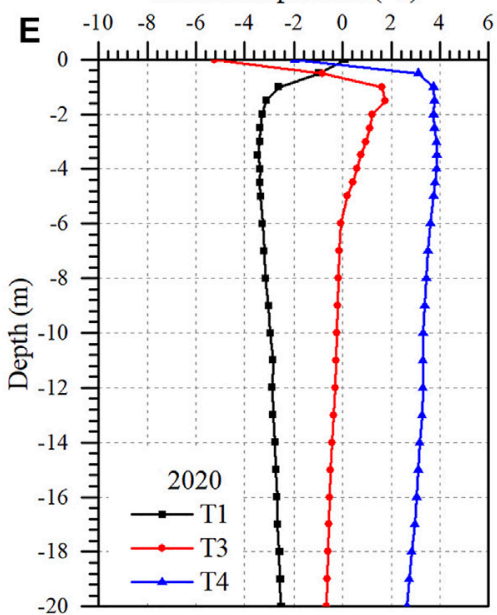

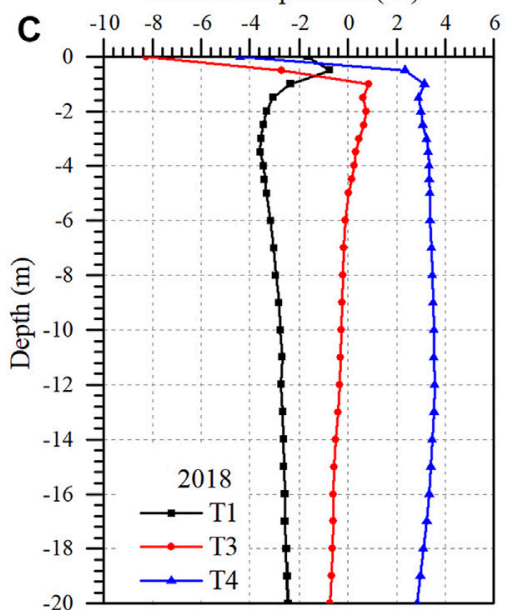
Ground temperature $\left({ }^{\circ} \mathrm{C}\right)$

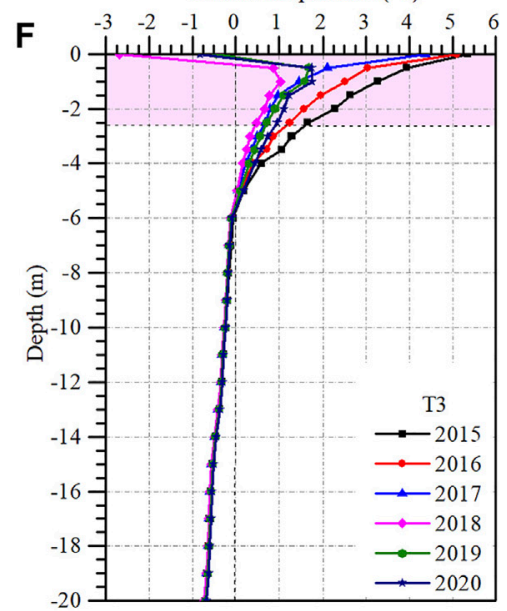
Ground temperature $\left({ }^{\circ} \mathrm{C}\right)$

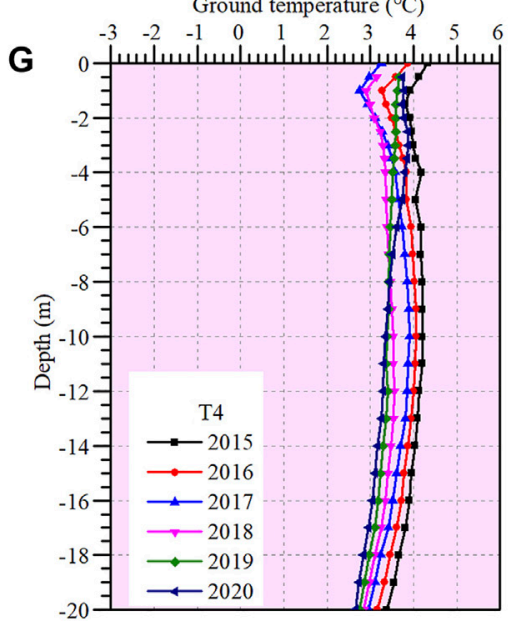

FIGURE 3 | Ground temperatures in the Gulianhe strip coalmine in the Hola Basin in the northern Da Xing'anling Mountains, Northeast China. Notes: (A,B) ground temperature-depth profiles in Boreholes T1 and T2 in the undisturbed area, respectively, in 2019; (C-E) mean annual temperatures of soil at all measured depths in Boreholes T1 (undisturbed area), T3 (2.6 m backfill), and T4 (20 m backfill), respectively, from 2018 to 2020; and (F,G) measured mean annual soil temperature at depths of 0-20 m in Boreholes T3 and T4 in the backfilled area, respectively, in 2015-2020. The rectangles in purple represent the depth of the backfilled layer. 


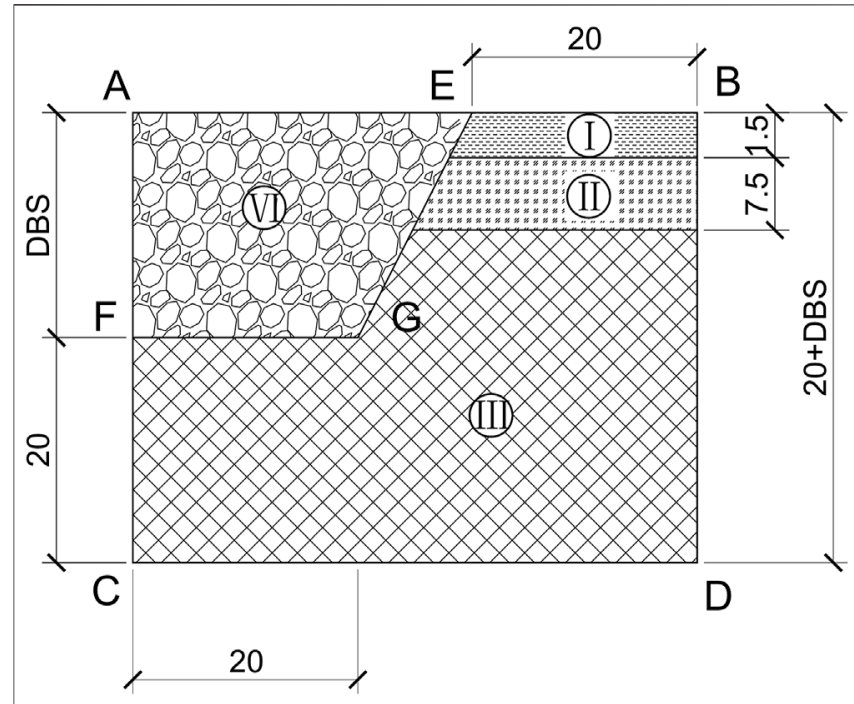

FIGURE 4 | Physical model of the pit backfill domain in the Gulianhe strip coalmine in the Hola Basin in northern Da Xing'anling Mountains, Northeast China.

Borehole T4 was established in the center of the backfilled zone, with a backfill thicker than $20.0 \mathrm{~m}$. The detailed information and lithology of four boreholes are shown in Table $\mathbf{1}$ and Figure 2.

Thermistor cables (with an accuracy of $\pm 0.05^{\circ} \mathrm{C}$ in the laboratory), assembled in the State Key Laboratory of Frozen Soils Engineering (SKLFSE), were permanently installed in encased steel tubes every $0.5 \mathrm{~m}$ at depths of $0-5 \mathrm{~m}$ and every $1.0 \mathrm{~m}$ at depths of $5-20 \mathrm{~m}$. Ground temperature was acquired by CR3000 data loggers in the undisturbed area (Boreholes T1 and T2) at a frequency of six times daily since October 2017. Ground temperatures in Boreholes T3 and T4 were manually measured every 10 or 15 days since September 2014.

\subsubsection{Monitoring Results and Analysis}

Figures 3A,B show the ground temperature-depth profiles of Boreholes T1 and T2 in the warm and cold seasons in 2019. For Borehole T2, the maximum seasonal thaw depth was approximately $2.5 \mathrm{~m}$, and the 3 -year average of $\mathrm{T}_{\mathrm{ZAA}}(10 \mathrm{~m})$ was $-0.43^{\circ} \mathrm{C}$, indicating an area of warm permafrost. At Borehole $\mathrm{T} 1$, the maximum seasonal thaw depth was about $1.6 \mathrm{~m}$, and the 3 -year average of $\mathrm{T}_{\mathrm{ZAA}}(15 \mathrm{~m})$ was close to $-2.83^{\circ} \mathrm{C}$.

Boreholes T3 and T4 are in the pit backfilled area after coal mining. Figures 3C-E show mean annual soil temperatures in Borehole T1 in the undisturbed area and Boreholes T3 and T4 from 2018 to 2020. Evidently, the thermal influence of coal mining on permafrost temperature is great and increases with backfill thickness.

For Borehole T3, annual maximum thaw depth increased from $2.6 \mathrm{~m}$ in 2018 to $6.0 \mathrm{~m}$ in 2020 . However, after pit backfilling, soil temperatures of the upper layer declined, indicating a rapidly cooling backfill. For Borehole T4, soil temperature was positive at depths of $0-20 \mathrm{~m}$ (Figures 3F,G), indicating a talik since backfilling. However, after backfilling in 2007, by comparing changes in mean annual soil temperatures in the observed
6 years (2015-2020), ground temperature was declining at an average cooling rate of $0.2^{\circ} \mathrm{C} / \mathrm{a}$.

Field observations indicate great impacts of coal mining on ground temperature, directly thawing permafrost in the mining area. However, ground temperature lowered after the pit backfilling, indirectly proving the good thermal effect of the backfill on ground thermal regimes.

\subsection{Mathematical Model Descriptions 2.3.1 Physical Models}

Recovery of permafrost can be evaluated by changes in ground temperature, the single most important indicator of the ground thermal state. Figure 4 shows the physical model of the backfilled domain. It is built on the actual permafrost distribution, mining status, and coalmine geometry. According to the results of borehole drilling, the original lithology at the backfilled location can be roughly divided into three layers, namely, sandy clay (Layer I), sand (II), and weathered sandstone (III), and layer IV (backfill) unconformably contacts with three of other layers in the upper boundaries. The surrounding area is assumed infinite in the computation. However, for convenience in calculation, we defined the horizontal and vertical dimensions in the thermally impacted range of mining areas and assumed an adiabatic boundary. The backfill area in the model is thus twodimensional and symmetrical. Therefore, half of the model domain is taken for calculation. We also assumed the spatial homogeneity for backfilled material and temperature distribution.

The basic assumptions of the numerical model calculation are as follows: 1) the thermal disturbance of the soil at the bottom of the pit is neglected after the pit is mined; that is, the ground temperature at the bottom of the pit is calculated based on the permafrost changes with depth in the natural state; 2) the backfill soil has uniform soil quality, porosity, and water content, regardless of the effect of water flow; and 3) the surface elevation after backfilling is consistent with the natural surface.

\subsubsection{Governing Equations}

Frozen soil is a relatively discrete porous medium, in which heat is mainly conducted in the soil, and convection, advection, and radiation can be ignored. It is assumed that soil layers are homogeneous and isotropic, without water replenishment and without heat convection due to water migration. For frozen soil with freeze-thaw cycles, the phase changes of ice-water need to be considered; heat convection and advection and other effects are ignored, and the unfrozen water content is only a function of temperature. Therefore, frozen soil undergoes an unsteady heat transfer process with phase change, and the equation of temperature field is governed by the following:

$$
C^{*} \frac{\partial T}{\partial t}=\frac{\partial}{\partial x}\left(\lambda^{*} \frac{\partial T}{\partial x}\right)+\frac{\partial}{\partial y}\left(\lambda^{*} \frac{\partial T}{\partial y}\right),
$$

where $C^{*}$ and $\lambda^{*}$ represent the effective volumetric heat capacity and thermal conductivity of soil, respectively, and $T$ is the soil temperature. Considering that the specific heat capacity and thermal conductivity of soil vary under freezing, frozen, thawing, and thawed conditions, and assuming that the 
TABLE 2 | Thermal parameters of different media (based on Leng, 2011; Liang et al., 2018; Yang, 2018; Pei et al., 2019; Mu et al., 2020).

\begin{tabular}{|c|c|c|c|c|c|c|}
\hline \multicolumn{2}{|c|}{ Thermal parameters } & \multirow{2}{*}{$\begin{array}{c}\mathrm{C}_{\mathrm{u}}(\ln \\
\left.\mathbf{1 0}^{\mathbf{6}} \mathrm{J} /\left(\mathbf{m}^{\mathbf{3}} \cdot \mathrm{K}\right)\right) \\
2.357\end{array}$} & \multirow{2}{*}{$\begin{array}{c}C_{f}(\ln \\
\left.\mathbf{1 0}^{\mathbf{6}} \mathbf{J} /\left(\mathbf{m}^{\mathbf{3}} \cdot \mathbf{K}\right)\right) \\
1.879\end{array}$} & \multirow{2}{*}{$\begin{array}{c}\lambda_{\mathbf{u}}(\mathbf{W} /(\mathbf{m} \cdot \mathbf{K})) \\
1.125\end{array}$} & \multirow{2}{*}{$\begin{array}{c}\lambda_{\mathbf{f}}(\mathbf{W} /(\mathbf{m} \cdot \mathbf{K})) \\
1.351\end{array}$} & \multirow{2}{*}{ 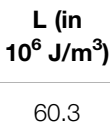 } \\
\hline Silty clay & & & & & & \\
\hline Gravel soil & & 3.170 & 2.210 & 1.060 & 1.380 & 132.0 \\
\hline Weathered rock & & 2.099 & 1.846 & 1.474 & 1.824 & 37.7 \\
\hline \multirow[t]{4}{*}{ Backfilling soil } & Pebbly sand & 2.456 & 1.825 & 1.450 & 1.651 & 20.4 \\
\hline & Crushed rock & 1.015 & 1.015 & 0.387 & 0.387 & 0 \\
\hline & Coal gangue & 1.800 & 1.800 & 0.251 & 0.251 & 0 \\
\hline & Sandy clay & 2.677 & 2.208 & 1.240 & 1.380 & 106.8 \\
\hline
\end{tabular}

ice-water phase changes occur in a temperature range $\left[\begin{array}{cc}T_{b} & , T_{p}\end{array}\right]$, the effective volumetric heat capacity $(C *)$ and effective thermal conductivity $(\lambda *)$ can be described as follows (Bonacina et al., 1972; Zhang M. et al., 2015):

$$
\begin{gathered}
C^{*}=\left\{\begin{array}{cl}
C_{f} & T<T_{b} \\
\frac{C_{f}+C_{u}}{2}+\frac{L}{T_{p}-T_{b}} & T_{b}<T<T_{p}, \\
C_{u} & T>T_{p}
\end{array}\right. \\
\lambda^{*}=\left\{\begin{array}{cc}
\lambda_{f} & T<T_{b} \\
\lambda_{f}+\frac{\lambda_{u}-\lambda_{f}}{T_{p}-T_{b}}\left(T-T_{b}\right) & T_{b}<T<T_{p}, \\
\lambda_{u} & T>T_{p}
\end{array}\right.
\end{gathered}
$$

where $C_{f}$ and $C_{u}$ refer to the volumetric heat capacity of frozen and unfrozen soils, respectively; $\lambda_{f}$ and $\lambda_{u}$ represent the thermal conductivity coefficient of frozen and unfrozen soils, respectively; and $L$ denotes the latent heat of phase change per unit volume. Thermal parameters of the different layers are listed in Table 2.

If the backfill material is crushed rock, the air on the rock layer flows under an unstable pressure gradient, so the convective heat transfer process of the air in the crushed rock should be considered (Pei et al., 2019), and then the governing equation of the crushed rock can be rewritten by the following equation:

$$
C_{c}^{*} \frac{\partial T}{\partial t}=\frac{\partial}{\partial x}\left(\lambda_{c}^{*} \frac{\partial T}{\partial x}\right)+\frac{\partial}{\partial y}\left(\lambda_{c}^{*} \frac{\partial T}{\partial y}\right)-C_{a i r} \rho_{a i r}\left(V_{x} \frac{\partial T}{\partial x}+V_{y} \frac{\partial T}{\partial y}\right)
$$

where $C_{c}^{*}$ is the effective volumetric heat capacity of crushed rock; $\lambda_{c}^{*}$ is the effective thermal conductivity of crushed rock; $C_{a i r}$ is the specific heat of air at a constant pressure, the value is taken as $1.004 \times 10^{4}(\mathrm{~J} /(\mathrm{kg} \cdot \mathrm{K})) ; \rho_{\text {air }}$ is the density of the air, the value is taken as $0.641\left(\mathrm{~kg} / \mathrm{m}^{3}\right)$; and $V_{x}$ and $V_{y}$ are the velocity components in the $x$ and $y$ directions, respectively, in the space coordinate system.

\subsubsection{Boundary and Initial Conditions}

\subsubsection{Boundary Conditions}

For this permafrost temperature numerical model, the boundary conditions are as follows:

\section{1) Upper boundary condition}

The upper surface temperature of the model is affected by air temperature, climate warming rate, solar radiation, precipitation, evaporation, and insulation effects of snow and vegetation covers (Wang et al., 2021b). According to Zhu (1988), temperature on the natural ground surface (Plane $\mathrm{AB}$ in Figure 4) varies as follows:

$$
T\left(t_{h}\right)=T_{0}+\frac{\Delta T_{\text {warm }}}{8760} t_{h}+A \times \sin \left(\frac{2 \pi}{8760} t_{h}+\frac{\pi}{2}+\alpha_{0}\right),
$$

where $T_{0}$ is the mean annual ground surface average temperature, taken as $-3.5^{\circ} \mathrm{C}$ (Luo et al., 2014); $\Delta T_{\text {warm }}$ represents the warming rate of MAAT, $0.05^{\circ} \mathrm{C} / \mathrm{a}$ (Jin et al., 2008); the annual amplitude of temperature $A$ is $23{ }^{\circ} \mathrm{C}$ based on the meteorological record at Mo'he, Heilongjiang Province, China; and $t_{h}$ is the time in hour.

Assuming a higher MAAT of the atmosphere-backfill boundary (AE) $\left[T\left(t_{h}\right)\right]$ than the natural ground surface $(\mathrm{AB})$, $\left(T\left(t_{h}\right)\right)$ is written as follows:

$$
T\left(t_{h}\right)=T_{0}+\Delta T+\frac{\Delta T_{\text {warm }}}{8760} t_{h}+A \times \sin \left(\frac{2 \pi}{8760} t_{h}+\frac{\pi}{2}+\alpha_{0}\right),
$$

where $\Delta T$ is the temperature increment and the value is $1.0^{\circ} \mathrm{C}$.

\section{2) Bottom boundary (Plane CD) condition}

The thermal boundary temperature gradient at the bottom of the model domain is small and relatively stable, which is taken as the second type of boundary condition, that is, the Neumann boundary condition of known heat flux density. According to regional geological data (Mu et al., 2020), the geothermal heat flux is taken as $0.04 \mathrm{~W} / \mathrm{m}^{2}$.

\section{3) Lateral boundary (Planes AC and BD) conditions}

According to the assumptions for the physical model, one of the lateral boundaries, namely, AC, is symmetrical, and the other boundary $\mathrm{BD}$ is adiabatic.

\subsubsection{Initial Conditions}

Due to the hydrothermal impacts of coal mining on geothermal fields of the periphery permafrost and active layer, observed values cannot be used as the initial temperature in model simulations. Thus, the initial ground temperature of the model is obtained by long-term transient calculation with the upper boundary conditions (Eq. 5) without considering climate 

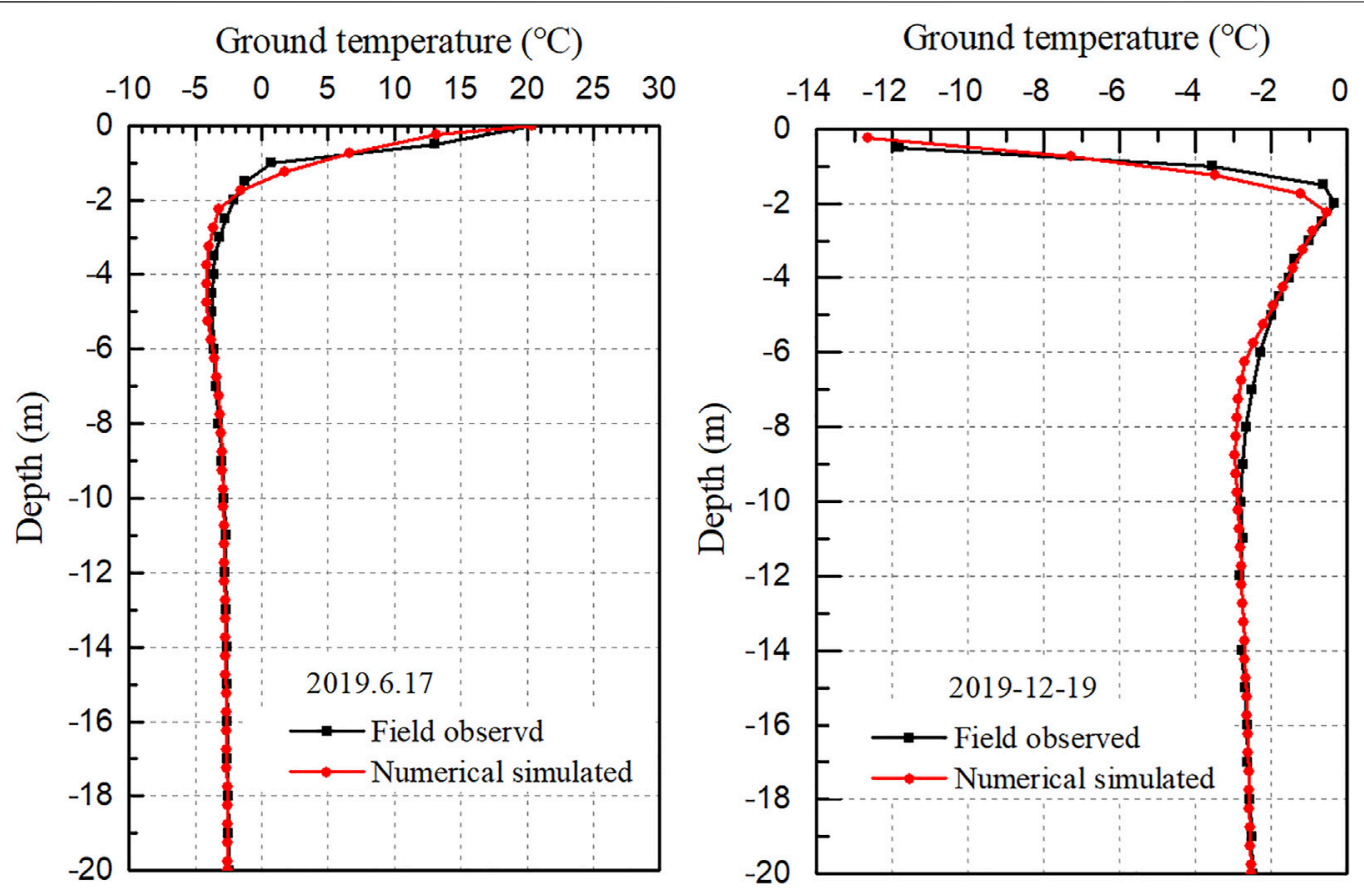

FIGURE 5 | Comparison between field observation data and numerical simulation results for ground temperatures in Borehole T1 at the undisturbed area in the Gulianhe strip coalmine in the Hola Basin in northern Da Xing'anling Mountains, Northeast China.

warming (Zhang et al., 2011) until the temperature field below the annual change layer remains basically unchanged, and ground temperature at the same location above the annual change layer remains the same every year.

\section{NUMERICAL SIMULATION RESULTS AND ANALYSES}

\subsection{Numerical Model and Parameterization Validation}

Validation and parameterization of numerical model are based on field monitoring data of ground temperature in Borehole T1. Numerical simulation results of ground temperatures in the permafrost zone are in good agreement with field monitoring data, as indicated in the similar changing trends of simulated and monitored ground temperatures (Figure 5). For the active layer, however, ground temperatures differ appreciably between the two (the numerical simulation result is about $0.15^{\circ} \mathrm{C}$ higher than the measured), which is possibly because of neglecting the insulation effect of surface vegetation and organic soil in the superficial layer in the numerical model. There are also certain deviations in model parameterization. Overall, simulation results are highly consistent with field observed data. Thus, the numerical model could be reliably used to evaluate the thermal influences of the pit backfilling.

\subsection{Numerical Simulation Conditions}

Strip coal mining activities have disturbed the thermal state of ambient and underlying permafrost. Large mine pits and subsequent water ponding and drainage would thaw the ambient and underlying permafrost of mine pits, possibly forming new taliks or expanding the nearby existing taliks. Therefore, mine pits should be timely backfilled after coal mining to facilitate permafrost and ecological recovery. However, annual average ground (backfill) and air temperatures, properties of backfilled soils, and pit depth are important factors for the hydrothermal recovery of the backfilled ground. Thus, four variables, that is, temperature of backfilling soils (TBS: $0,2,5,10,15$, and $20^{\circ} \mathrm{C}$ ), depth of backfill soils (DBS: 2.6, 5, 10, 15,20 , and $30 \mathrm{~m}$ ), moisture content of backfilled soils (MCBS: 10, 15, 20, 25, 30, and 35\%), and material of backfill soils (MBS: crushed rock, pebbly sand, coal gangue, and sandy clay), were evaluated in model simulations for a time span of over 50 years.

\subsection{Influencing Factors for Long-Term Ground Temperature Recovery \\ 3.3.1 Temperature of Backfilling Soil}

After pit backfilling, the heat brought into the ground by the backfilled soil cannot dissipate immediately and completely. Heat dissipation would affect the temperature of ambient soils, even leading to the thawing of the underlying and ambient permafrost. TBS is important for the recovery time of ground temperature (Gao et al., 2017). Thus, mine pits should be backfilled timely, preferably in cold seasons, for rapid recovery of ground temperature field. In this study, the modeled pit is $20 \mathrm{~m}$ deep and backfilled with pebbly sand. Four cases with different TBS (0, $2,5,10,15$, and $20^{\circ} \mathrm{C}$ ) are analyzed and evaluated (Figure 6).

Variations in centerline ground temperature of the backfilled ground over the next 50 years are shown in Figure 6. Evidently, TBS has an important effect on the 


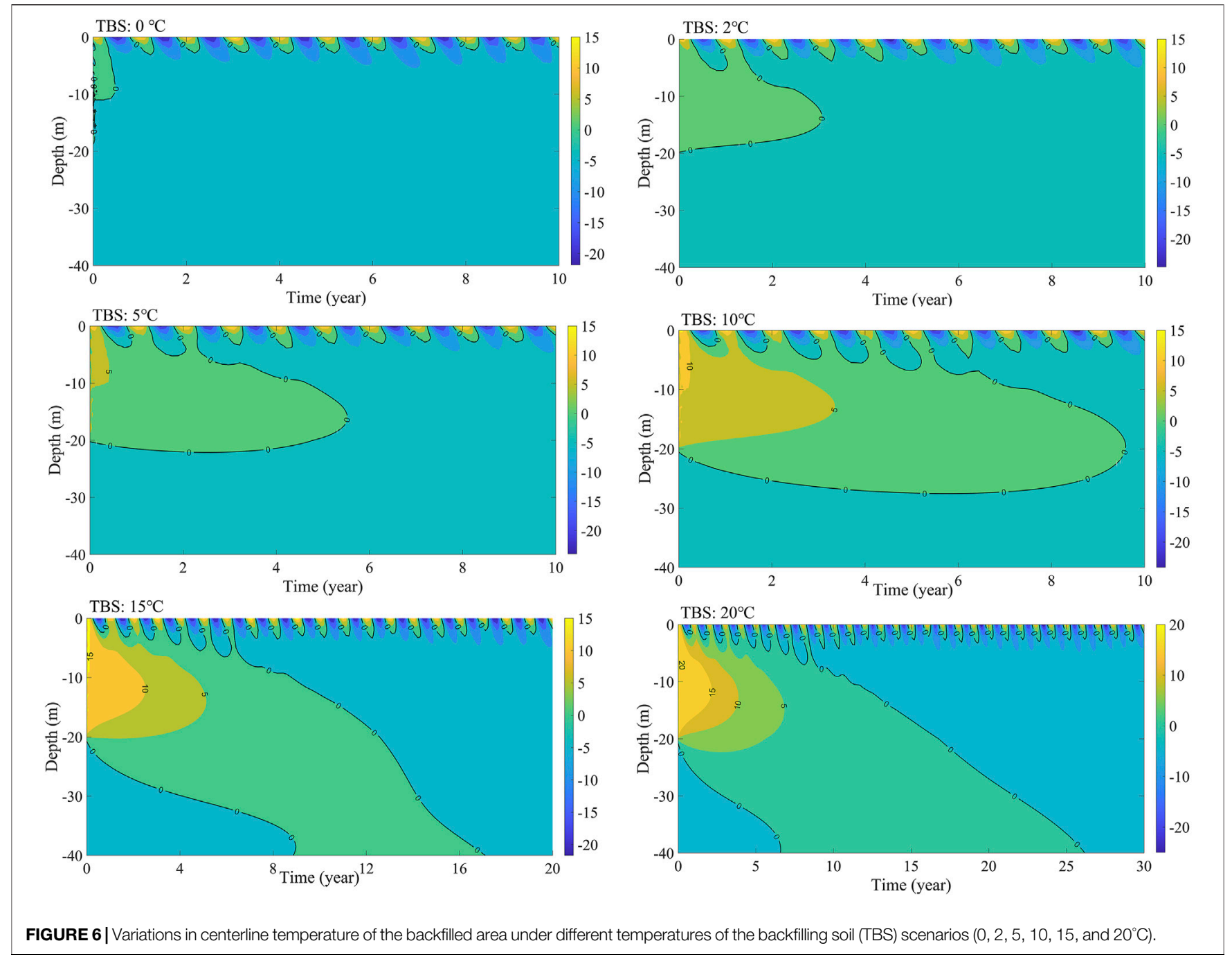

thermal recovery. TBS has a negative correlation with the thermal recovery time due to the main conductive mode of heat transfer in soil; to cool the warmer soil, more heat needs to be released. Thus, it takes more time to re-balance with the ambient environment. Clearly, regardless of other factors, when the TBS is $0,2,5,10,15$, and $20^{\circ} \mathrm{C}$, the ground temperature recovery time would be $0.3,3.7$, 9,17 , and 26 years, respectively. Notably, as TBS increases, heat transfer between the backfilled ground and ambient permafrost gradually increases; meanwhile, it takes longer to cool and freeze the ground. Figure 7 shows the non-linear growth relationship between TBS and recovery time of the backfilled pit, and the relationship can be fitted as follows:

$$
t_{r}=32.05 \times e^{-0.027 T}-30.82,
$$

where $t_{r}$ is the recovery time (a) and $T$ is the TBS (temperature of the backfilling soil).

\subsubsection{Depth of Backfilled Soil}

The deeper the excavated pit of strip coalmine, the greater scope and scale of thermal impacts on ambient soils. Especially in permafrost regions, it will take longer time for areas with deep pits to freeze back after backfilling. Six cases with different DBS $(2.6,5,10,15,20$, and $30 \mathrm{~m})$ were analyzed in this study (Figure 8). The simulation parameters (TBS at $15^{\circ} \mathrm{C}$ and MBS, pebbly sand) are used to analyze and evaluate the ground temperature distribution. As DBS increases, the thermal recovery also prolongs (Figure 8). For example, when the DBS is $2.6 \mathrm{~m}$, ground temperature would recover in the second year after backfilling, while when the DBS reaches $30 \mathrm{~m}$, it will take 50 years for ground refreezing. At the same time, after backfilling, permafrost at the lower part of pit is thermally affected by backfilling, and ground temperature rises and permafrost thaws, forming a thawed interlayer.

As shown in Figure 9, there is a non-linear growth relationship between the recovery time and DBS, as follows:

$$
t_{r}=8.021 \times e^{-0.027 H}-8.734,
$$

where $t_{r}$ is the recovery time (a) and T is the DBS (depth of backfilled soil). 


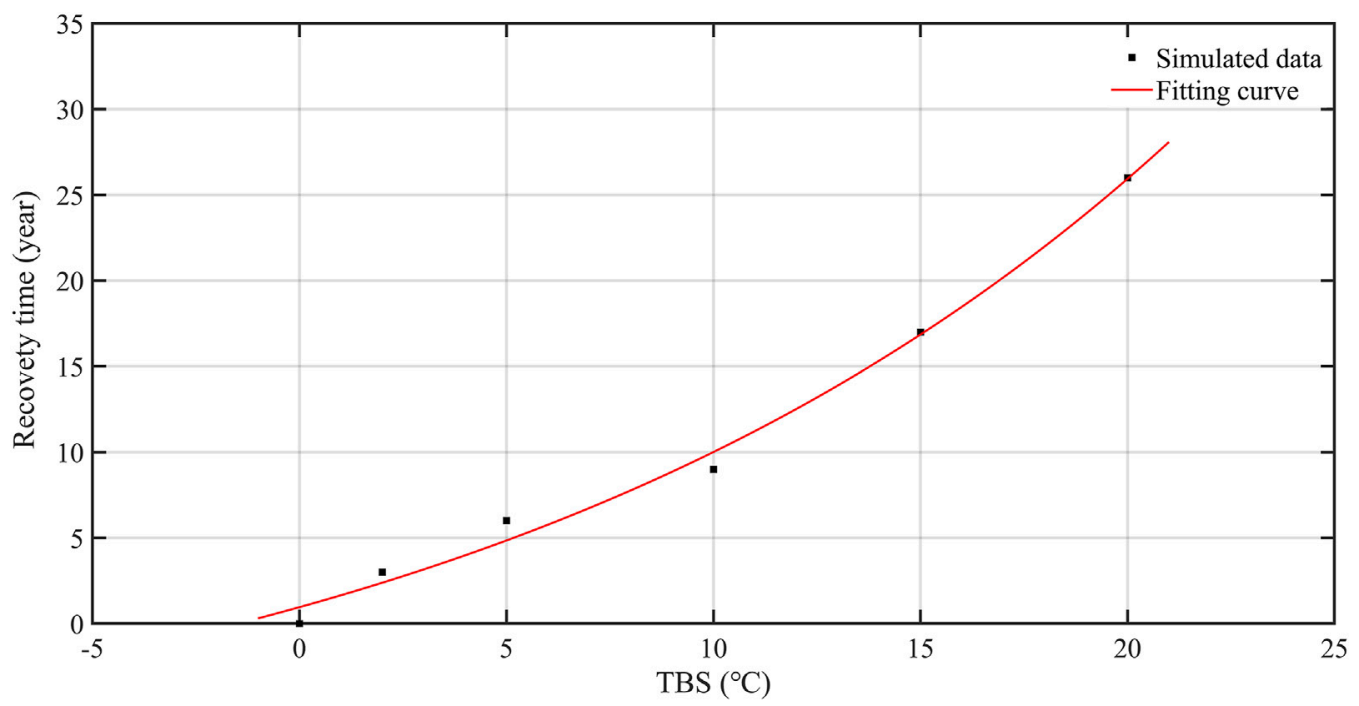

FIGURE 7 | Relationship between temperature of the backfilling soil (TBS) and the recovery time of ground temperature.

\subsubsection{Moisture Content of Backfill Soil}

Thermophysical parameters of soil, such as heat conductivity, heat capacity, and latent heat, were strongly affected by soil moisture content. Table 3 shows the thermophysical parameters of sandy clay under different water contents. Thermophysical parameters of soils vary with soil moisture content, and different heat transfer capacities of varied soils affect the thermal recovery of permafrost. Therefore, MCBS needs to be considered for studying the influence factors of pit backfilling on the recovery of ground thermal regimes.

Figure 10 shows variations in ground temperatures of backfill centerline with six ascending MCBS (10, 15, 20, 25, 30, and 35\%) under the conditions of $15^{\circ} \mathrm{C}$ in TBS, $20 \mathrm{~m}$ in DBS, and sandy clay in MBS. Apparently, the recovery time of ground temperature is closely related to MCBS (Figure 10). When moisture content of sandy clay is $15-25 \%$, it would take about 50 years for the ground to freeze-up and about 95 years for moisture content higher than 25\%. However, 75 years would be needed for the thermal recovery with MCBS at lower than $15 \%$. Thus, near the optimal moisture content of sandy clay at $15-25 \%$, permafrost would recover most rapidly.

As shown in Figure 11, the recovery time of ground temperature is related to the optimal soil moisture content of backfill. When MCBS is near the optimal soil moisture content, the ground temperature field recovers the most rapidly; otherwise, it takes longer. The relationship between MCBS and recovery time can be fitted as follows:

$$
t_{r}=0.202 \times(w-19.62)^{2}+52.91,
$$

where $t_{r}$ is the recovery time (a) and $w$ is the MCBS (moisture content of the backfilling soil, \%).

\subsubsection{Material of the Backfill Soil}

Recovery time of permafrost in the backfilled area differs distinctly because of highly variable thermophysical parameters of different backfilled soils. All four backfill types (crushed rock, pebbly sand, coal gangue, and sandy clay) are simulated under the case of DBS at $20 \mathrm{~m}$ and TBS at $15^{\circ} \mathrm{C}$ (Figure 12). As shown in Figure 12, it takes the shortest time to recover the permafrost by backfilling with crushed rock, indicating the good cooling effect of crushed rock. Along the Qinghai-Tibet railway, this was also validated in the case of crushed rock subgrade (Lai et al., 2009; Zhang L. et al., 2015; Pei et al., 2019). Compared with crushed rock, the cooling time required for backfilling with pebbly sand would be relatively longer, almost twice that of crushed rock. This is mainly because that the specific surface area, specific heat, and heat conduction of pebbly sand are larger than those of crushed rock. At the same time, the backfilling of pebbly sand may thaw the permafrost at the pit bottom down to about $12 \mathrm{~m}$ in depth. The time for coal gangue/slag backfill to restore its ground temperature field would be about 20 years and that of sand clay would be 41 years, and the permafrost $20 \mathrm{~m}$ under the backfill would be affected. Among the four simulated materials (MBS), the time required for sandy clay backfilling would be the longest, and the depth of thermal impact on the underlying permafrost would be the largest.

\section{DISCUSSION}

Due to the sensitivity and vulnerability of the boreal permafrost ecological environment, strip coal mining and ground facility construction inevitably result in environmental damage to varied extents, thus accelerating the degradation of Xing'an permafrost in Northeast China. Particularly, abundant open pits have been dug for coal mining, with substantial impacts on the surrounding and underlying permafrost. According to observations, open pits receive remarkably more solar radiation. Therefore, air temperatures in pits are $0.5-1.2^{\circ} \mathrm{C}$ higher than those in surrounding areas, forming a distinct local climate in pits and influencing ambient and underlying permafrost (Zheng et al., 


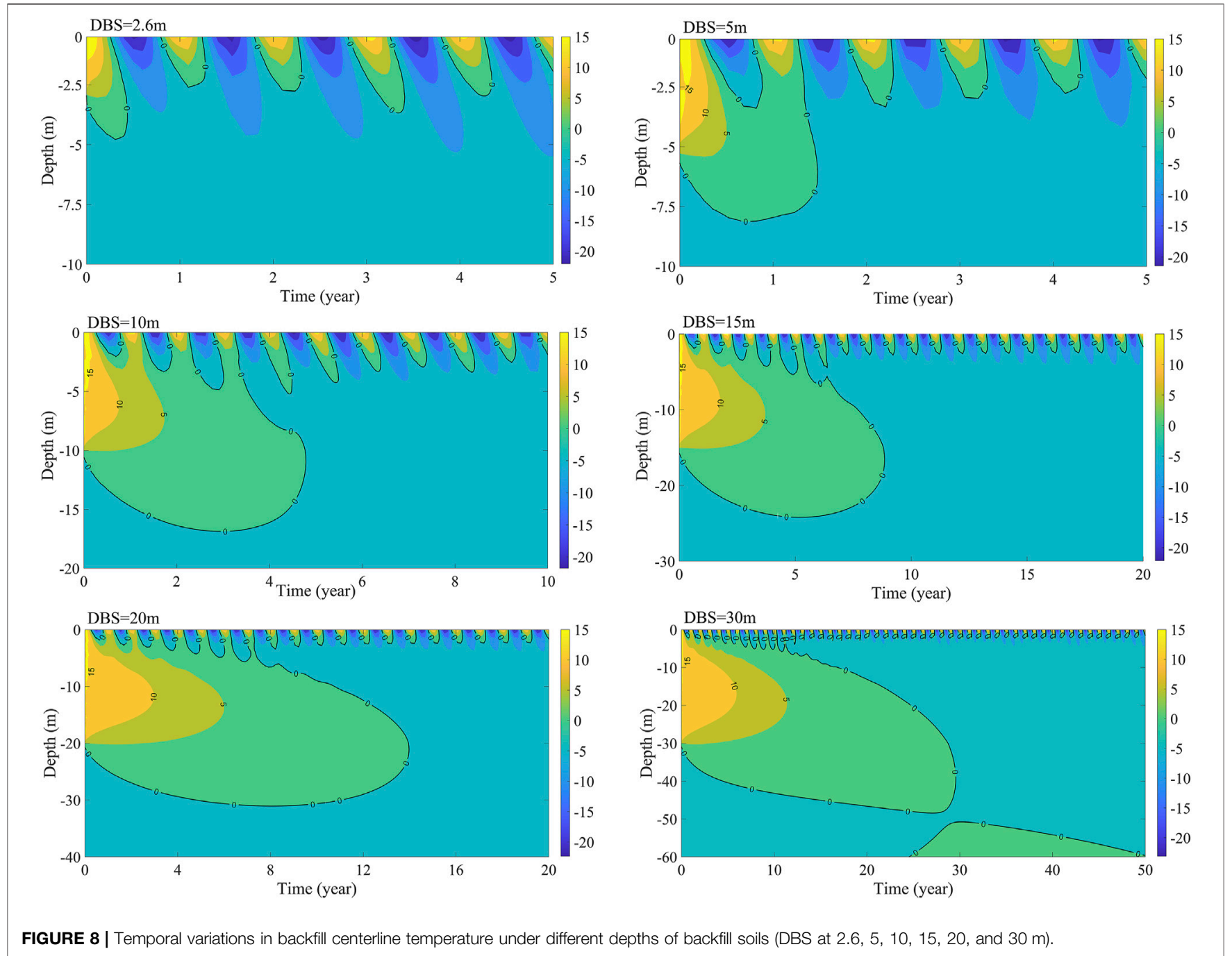

FIGURE 8 | Temporal variations in backfill centerline temperature under different depths of backfill soils (DBS at 2.6, 5, 10, 15, 20, and 30 m).

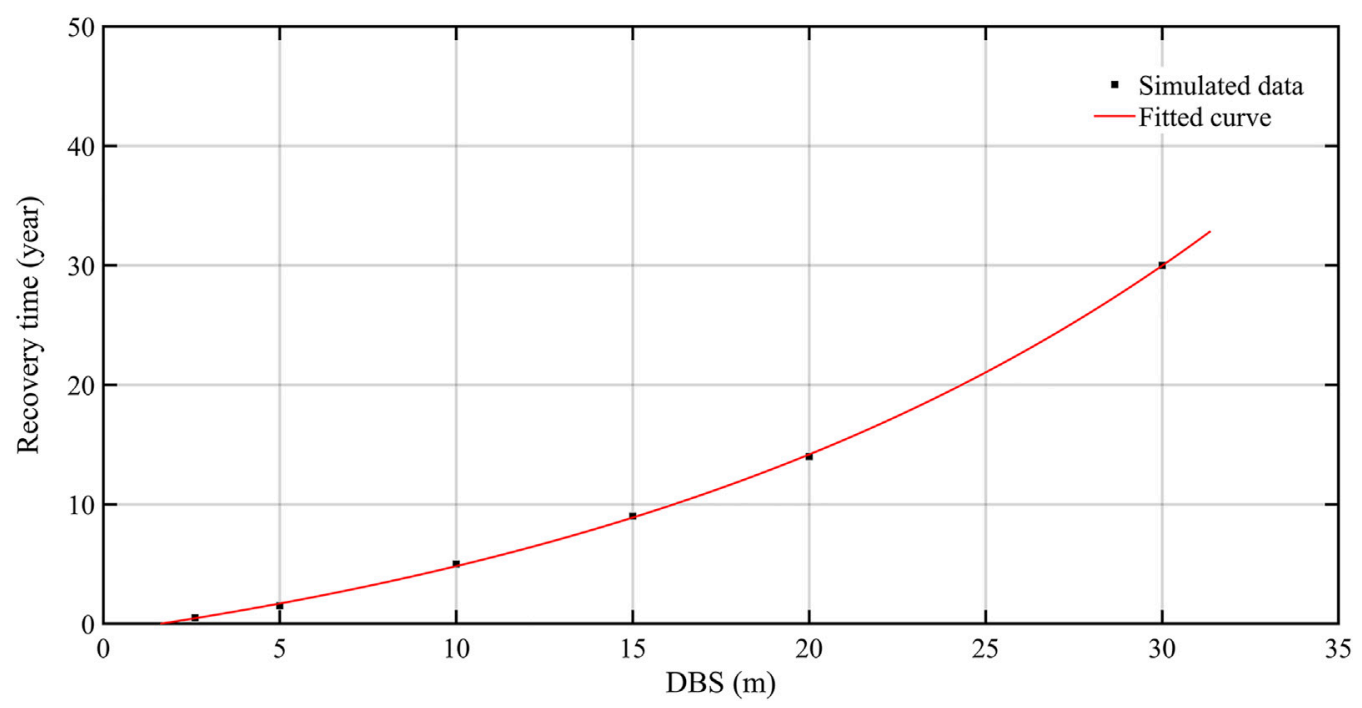

FIGURE 9 | Regression relationship between the depths of backfill soils (DBS) and the recovery time of ground temperature. 
TABLE 3 | Physical parameters of sandy clay at different moisture content (Chen et al., 2018; Han et al., 2019; Xu et al., 2001).

\begin{tabular}{|c|c|c|c|c|c|}
\hline \multirow{2}{*}{$\begin{array}{l}\text { Moisture content of } \\
\text { sandy clay }(\%)\end{array}$} & \multicolumn{2}{|c|}{ Thermal conductivity $[\mathrm{W} /(\mathrm{m} \cdot \mathrm{K})]$} & \multicolumn{2}{|c|}{ Volume heat capacity $\left[\right.$ in $\left.10^{6} \mathrm{~J} /\left(\mathrm{m}^{3} \cdot \mathrm{K}\right)\right]$} & \multirow{2}{*}{$\begin{array}{c}\begin{array}{c}\text { Latent } \\
\text { heat (in } 10^{6} \mathrm{~J} / \mathrm{m}^{3} \text { ) }\end{array} \\
\mathrm{L}\end{array}$} \\
\hline & $\lambda_{\mathbf{u}}$ (unfrozen) & $\lambda_{\mathrm{f}}$ (frozen) & $\mathrm{C}_{\mathrm{u}}$ (unfrozen) & $C_{f}$ (frozen) & \\
\hline 10 & 0.78 & 0.74 & 2.426 & 1.874 & 53.39 \\
\hline 15 & 1.11 & 1.02 & 2.342 & 2.041 & 80.08 \\
\hline 20 & 1.24 & 1.38 & 2.677 & 2.208 & 106.8 \\
\hline 25 & 1.28 & 1.80 & 3.011 & 2.375 & 133.5 \\
\hline 30 & 1.42 & 2.12 & 3.346 & 2.543 & 160.2 \\
\hline 35 & 1.54 & 2.40 & 3.681 & 2.710 & 186.9 \\
\hline
\end{tabular}

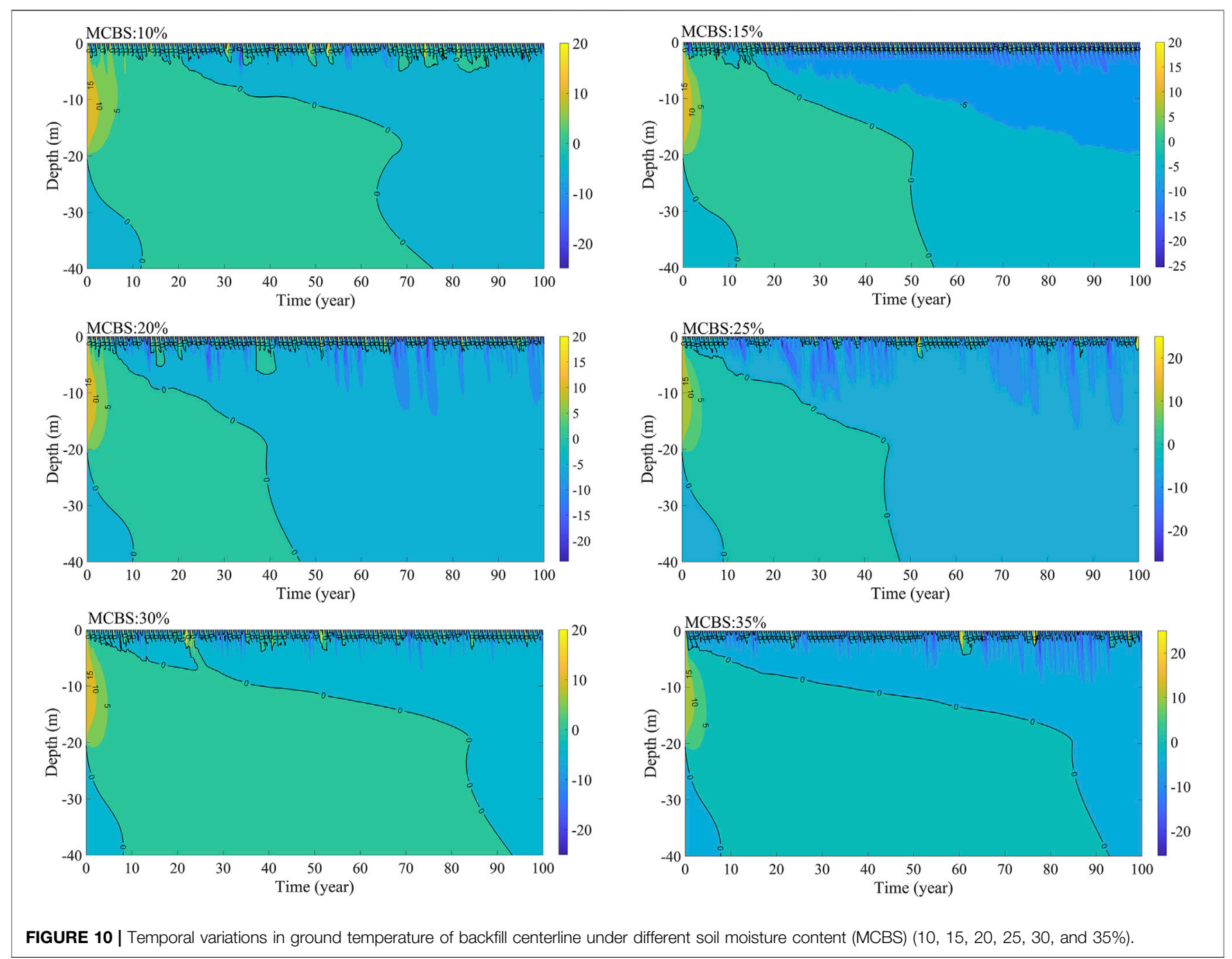

2000). Moreover, excavation of pits in areas with thin permafrost layers may thaw through the underlying permafrost. Therefore, timely and proper backfilling of open pits in the mining area is crucial to the effective recovery of the permafrost ecological environment. However, limited by many factors, slow recovery of the permafrost environment after backfilling, or even the thaw of permafrost, may influence ground temperature and water conditions in the backfilled areas; this surely will further affect the restoration of vegetation and the ecological environment (Wang et al., 2001; Li et al., 2014; Cao et al., 2016; Gao et al., 2017).

In this study, thermal recovery of permafrost after backfilling was analyzed and predicted through numerical simulations. The simulation results show a gradual recovery of ground temperature field in open pits in permafrost regions over time if backfilled timely. Ground temperatures of backfilled pit are affected by 


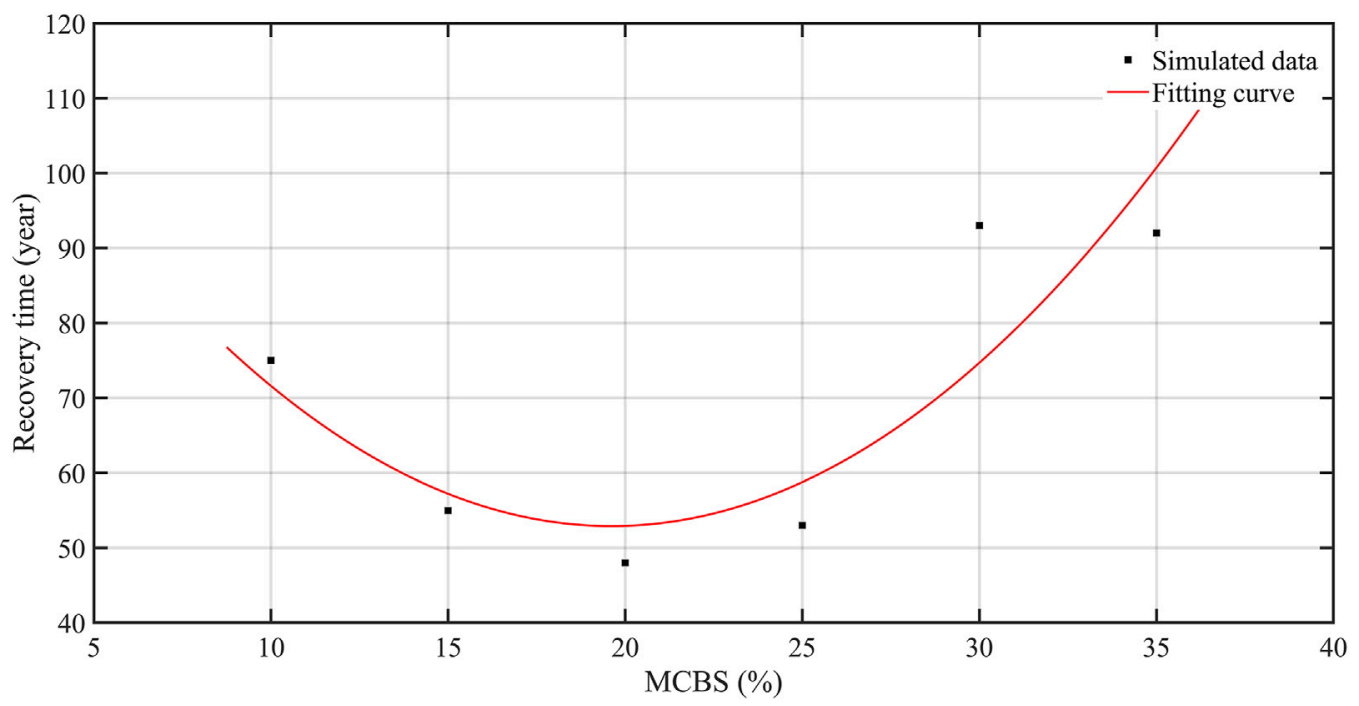

FIGURE 11 | Relationship between soil moisture content (MCBS) and the ground temperature recovery time.
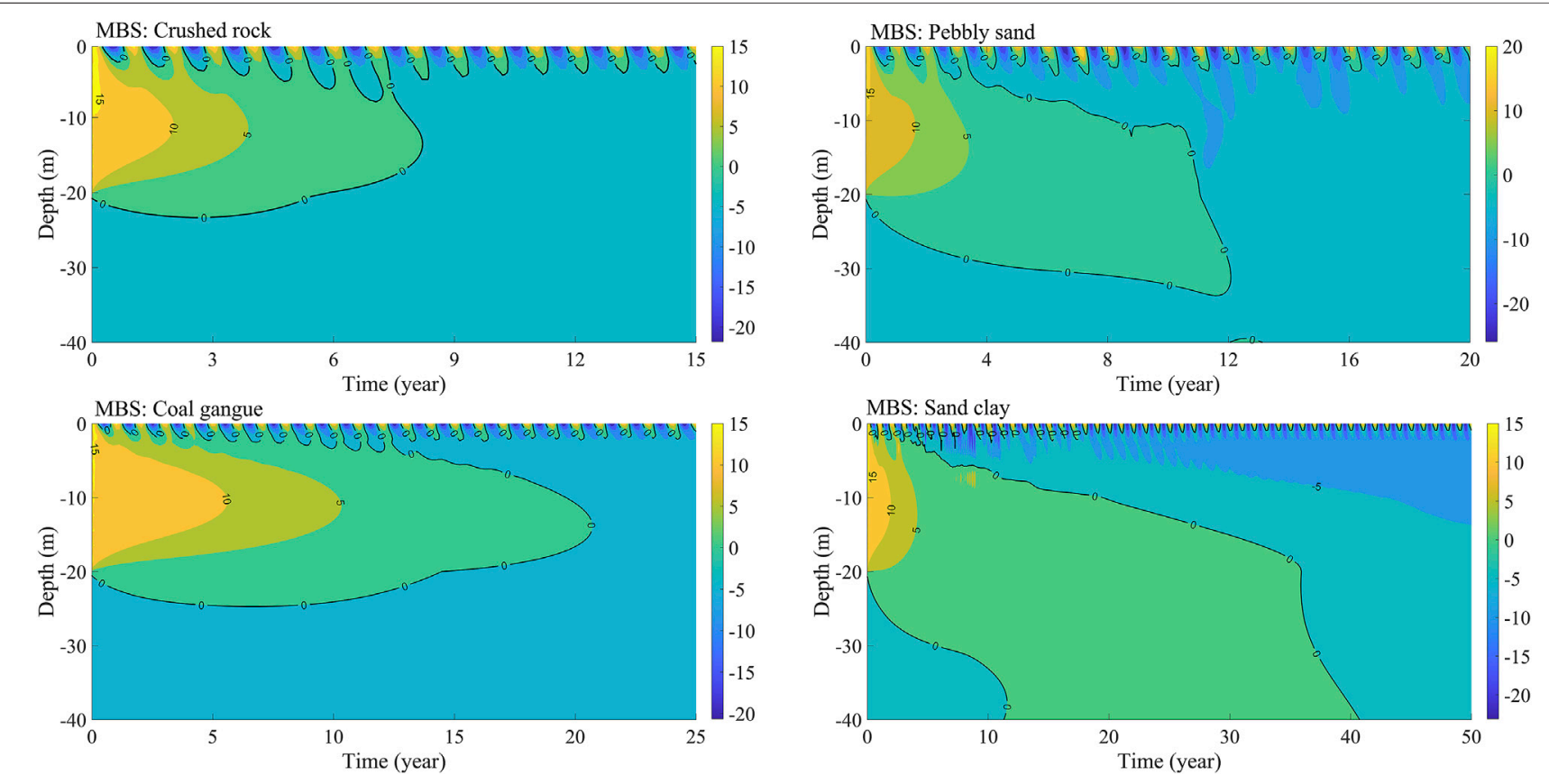

FIGURE 12 | Temporal variations in centerline temperature of different backfill soils (crushed rock, pebbly sand, coal gangue, and sand clay).

temperature, thickness, moisture content, and material types of backfill. The time of ground freeze-up is used to judge the degree of influence factors. First, temperature difference between backfill and surrounding permafrost induces heat transfer. Warm backfill may thaw the surrounding permafrost. In addition, it will take longer time to refreeze the backfilled ground. Then the thicker the backfill, the greater the thermal disturbances to the ambient permafrost, and the longer to refreeze the backfill. Model simulation results in our study are consistent with those in previous studies (e.g., Li et al., 2014; Cao et al., 2016; Gao et al., 2017). Some effective measures have been proposed in previous studies from perspectives of construction seasons, backfilling modes, and backfilling soil temperature. For example, it is advised for backfilling in cold seasons. Moreover, backfill thickness is a high-sensitivity factor, and layered backfilling can be implemented in cold seasons of different years for accelerating the thermal recovery in permafrost regions. 
Climate warming is evident in Northeast China (Jin et al., 2008; Luo et al., 2014; Zhang et al., 2021). Under a warming climate, how to recover the temperature in the backfilled areas in permafrost regions in shorter time? The unique or azonal distribution of the ecosystem-protected permafrost and talik at regional to landscape scales in Northeast China gives us some enlightenments. Under certain conditions, local factors affect the occurrence or temperature of permafrost by modifying radiation, convection, and conduction processes in the ground and on the ground surfaces (Cheng, 2004). Simulation results demonstrate that except for backfilling temperature, water content, and depth/ thickness of backfilled soil, backfilled soil types are key to the thermal recovery of permafrost. Based on these enlightenments from influencing mechanisms of local geo-environmental factors (Cheng, 2004), changes in backfilling material types and structures and modes in heat transfer, as well as comprehensive regulation measures, can be used for ground cooling in the backfilled areas for offsetting climate warming and for thermal recovery of permafrost in shorter time.

Many observational studies have suggested that the mean annual soil temperature in permafrost regions under crushed rock is $4-7^{\circ} \mathrm{C}$ lower than that in surrounding permafrost (Romanovskij and Turin, 1986; Harris, 1996; Harris and Pedersen, 1998; Gorbunov and Seversky, 2001). This was attributed to the Balch effect (Blach, 1900; Cheng, 2004). In winter, density of cold air is higher than that of hot air. Hence, cold air drains into stockpiles through large pores of rocks and squeezes out the hot air with small density in pores, forming convection, thereby enhancing heat loss. In summer, hot air occupies the upper spaces, while cold air stays low. There are relatively stable stratification and insignificant convection. Heat exchange is mainly based on heat conduction. Due to the extremely small thermal conductivity of air [only $0.025 \mathrm{~W} /$ $(\mathrm{m} \cdot \mathrm{K})]$, the heat exchange rate is minor. The annual balance of heat exchange results in stronger heat dissipation than heat absorption, thus cooling the ground. Simulation results in this study also show that compared with sandy clay, pebbly sand, and coal gangues, temperature in the backfilling region recovers more quickly when backfilled with crushed rock. This result confirms those conclusions on the cooling effect of the crushed rock foundation on the Qinghai-Tibet Plateau (e.g., Cheng, 2004; Lai et al., 2009). As a result, taking into account the Balch effect and the principle of convection regulation, crushed rock is more effective for backfilling mine pits to recover permafrost in shorter time.

Furthermore, in this study, only single material backfilling has been considered in numerical simulations. In fact, a new backfilling structure can be conceived. For example, an organic soil layer can be paved atop of the crushed rock layer for vegetation restoration and for maintaining the thermal state of underlying permafrost due to its good water-holding capacity and the thermal diode effect. In summer, the dry organic soil layer has poor thermal conductivity, and it can effectively impede heat conduction, weakening the warming of the underlying soil. In autumn and rainy season, the organic soil layer can be kept watersaturated. In winter, the thermal conductivity of ice-saturated, organic soil increases dramatically (He R. et al., 2021). In a word, it loses heat more effectively from the underlying soil into the atmosphere, effectively cooling and protecting the underlying permafrost. Moreover, due to the different thermal conductivity of organic soil under frozen and thawed states, large thermal offsets occur between the ground surface and at the permafrost table (Smith and Riseborough, 2002; Luo et al., 2018, 2020; Du et al., 2022). Due to the thermal offset, regions with a positive mean annual ground surface temperature, or those beyond permafrost zones, might occasionally generate or preserve permafrost (Smith and Riseborough, 2002; Cheng, 2004; Jin et al., 2008; He R.-X. et al., 2021). From the perspective of heat transfer control, the recovery of permafrost can be accelerated by configuring the structure of the backfilling layer and adding a layer of organic soil on the surface.

Some studies indicate that vegetation can reflect $10-23 \%$ of insolation, and green grasses in sedge (Carex tato) wetlands and other shrub marshlands can even reflect $23-28 \%$ of insolation (Wang et al., 1999). Dense vegetation can shield direct radiation and scattered radiation of solar energy, thus reducing net radiation onto ground surfaces (Tyrtikov, 1956; Kelley et al., 2004). Therefore, it is suggested to adopt reasonable planting in accordance with local situations after backfilling. For example, herb and shrub species can be combined. Herbs protect the ground surface from erosion, and they are beneficial in maintaining water and soils in early stage of backfilled areas. Shrubs not only are characteristics of strong resistance to drought, strong water-soil retention, and prevention of wind erosion but also grow quickly, and they are highly tolerant to and can quickly colonize barren lands. Besides, root sprouts of shrubs can extend into soil parent materials to immobilize weathering soil layers and stabilize slopes while absorbing nutrients. The combined planting of herbs and shrubs can shield direct and scattered solar radiation, and reduce heats into underlying soil, which is beneficial to thermal recovery of permafrost.

In a word, pit backfilling in permafrost regions may choose appropriate season first, such as the cold season. Second, the backfilling materials and structure shall be designed on purpose according to the principle of radiation, convection, and conduction regulation and comprehensive regulation, thus effectively cooling ground and even offsetting the climate warming. However, in this study, only a qualitative discussion was conducted on the feasibility of accelerating permafrost recovery by changing backfilling materials and structures. Specific measures may need a series of tests and practice to further determine key parameters per se.

Furthermore, it is worth noting that with strip mining, ambient permafrost is disturbed, accelerating ground thawing. As the mining continues to deepen, permafrost thaw would accelerate. In addition, precipitation and subsequent infiltration, surface runoff, and thawing permafrost will collect water at the pit bottom, affecting the backfill refreezing. However, these factors and climate-induced impacts are not considered in this study. Therefore, our simulation results may have overestimated the time or possibility of permafrost recovery. Thus, more practical and sound conclusions would need more improvement in monitoring and modeling. 


\section{CONCLUSION}

Strip coal mining has caused serious degradation of ambient permafrost. After backfilling, the slow rate of ground re-freezing in the mining area will affect soil moisture distribution, subsequently affecting the vegetation recovery. The recovery of permafrost in the backfilled area after coal mining is important for restoring the permafrost and the ecological environment. This study mainly presents the results of ground temperature monitoring to study influences of pit backfilling in Northeast China; combined with numerical simulation results, influencing factors for backfill temperature were analyzed. The main conclusions were drawn as follows:

1) By comparing ground temperatures at backfilled and undisturbed areas, backfilling has caused serious degradation of permafrost. The results of six-year monitoring data at the backfilled areas in permafrost regions show that a timely backfilling have a good effect on ground temperature recovery.

2) Regardless of the disturbances of ground temperature caused by climate warming and mining activities, the temperature of backfill soil (TBS), depth of backfill soil (DBS), moisture content of backfill soil (MCBS), and material of backfill soil (MBS) have great impacts on the recovery of the ground temperature field. Among them, the higher the backfilling temperature, the greater the backfill depth and the longer the ground temperature recovery time. Permafrost recovery time of backfill with finer particles, such as sandy clay and coal gangues, is longer. In addition, numerical simulations indicate a close relationship of permafrost recovery time and the optimal moisture content of backfill. When MCBS is close to the optimal soil moisture content, the ground refreezes most rapidly; otherwise, ground freezing would be slow.

3) Based on numerical simulation results and combining with enlightenments from azonal distribution of the ecosystemprotected Xing'an permafrost in Northeast China, it is possible to lower ground temperature and even offset the

\section{REFERENCES}

Bell, F. G., Bullock, S. E. T., Halbich, T. F.J., and Lindsay, P. (2001). Environmental impacts associated with an abandoned mine in the Witbank Coalfield, South Africa. International Journal of Coal Geology 45 (2-5), 195-216. doi:10.1016/ S0166-5162(00)00033-1

Blach, E. S. (1990). Glaciers or Freezing Caverns. Philadelphia: Allen, Lane and Scott, 1-337.

Bonacina, C., Comini, G., Fasan, A., and Primicerio, M. (1972). Numerical Solution of Phase-Change Problems. Int. J. Heat Mass. Transf 16 (10), 1825-1832. doi:10.1016/0017-9310(73)90202-0

Booshehrian, A., Wan, R., and Su, X. (2020). Hydraulic Variations in Permafrost Due to Open-Pit Mining and Climate Change: a Case Study in the Canadian Arctic. Acta Geotech. 15, 883-905. doi:10.1007/s11440-019-00786-x

Burov, B. A., and Gresov, A. I. (2011). Influence of Coal Deposits on Permafrost Degradation in the Shelf Zone of Arctic Seas and Methane Emission into the Water Column. Dokl. Earth Sc. 440 (1), 1320-1323. doi:10.1134/ s1028334x11090157 influences of climate warming by choosing the right backfill material types, configuring new backfill structures, as well as through a heat transfer mode regulation. Therefore, it is recommended that low temperature and composite structure of organic soil and crush rock layers should be used for backfilling after coal mining in permafrost regions, and the backfilled area should be timely and properly revegetated.

\section{DATA AVAILABILITY STATEMENT}

The raw data supporting the conclusion of this article will be made available by the authors, without undue reservation.

\section{AUTHOR CONTRIBUTIONS}

$\mathrm{RH}, \mathrm{YL}$, and $\mathrm{HJ}$ contributed to the conceptualization and writing of the manuscript. HW, XJ, MZ, XL, YH, DJ, and FM contributed to data collection and data compilation. All authors contributed to the article and approved the submitted version.

\section{FUNDING}

This study was financially supported by the National Natural Science Foundation of China (NSFC Grant Nos 41401081 and 41871052), the State Key Laboratory of Frozen Soils Engineering (Grant No. SKLFSE-ZT-41), the Strategic Priority Research Program of the Chinese Academy of Sciences (CAS) (Grant No. XDA20100103), and the Northwest Institute of EcoEnvironment and Resources (Grant No. E1550601).

\section{ACKNOWLEDGMENTS}

We thank the editor and the two reviewers for constructive and detailed comments on the article.

Cao, W., and Sheng, Y. (2013). Permafrost Environment Problems and Countermeasures in the Process of Coal Mining. Hydrogeol Eng. Geol. 40 (5), 91-96. (in Chinese).

Cao, W., Sheng, Y., Qin, Y., Li, J., and Wu, J. (2011). An Application of a New Method in Permafrost Environment Assessment of Muli Mining Area in Qinghai-Tibet Plateau, China. Environ. Earth Sci. 63, 609-616. doi:10.1007/ s12665-010-0728-7

Cao, W., Sheng, Y., Wu, J., Li, J., Li, J., and Chou, Y. (2016). Simulation Analysis of the Impact of Excavation Backfill on Permafrost Recovery in an Opencast Coal-Mining Pit. Environ. Earth Sci. 75 (9), 837. doi:10.1007/s12665-0165659-5

Chen, L., Yu, W., Yi, X., Hu, D., and Liu, W. (2018). Numerical Simulation of Heat Transfer of the Crushed-Rock Interlayer Embankment of Qinghai-Tibet Railway Affected by Aeolian Sand Clogging and Climate Change. Cold Regions Sci. Tech. 155, 1-10. doi:10.1016/j.coldregions. 2018. 07.009

Cheng, G. (2004). Influences of Local Factors on Permafrost Occurrence and Their Implications for Qinghai-Xizang Railway Design. Sci. China Ser. D-earth Sci. 47, 704-709. doi:10.1007/bf02893300 
Demirel, N., Emil, M. K., and Duzgun, H. S. (2011). Surface Coal Mine Area Monitoring Using Multi-Temporal High-Resolution Satellite Imagery. Int. J. Coal Geology. 86 (1), 3-11. doi:10.1016/j.coal.2010.11.010

Ding, D. W. (1988). Theoretical Study on Thermodynamics of Frozen Ground in China. J. Glaciol Geocryol 10 (3), 312-318. (in Chinese).

Du, R., Peng, X., Frauenfeld, O. W., Sun, W., Liang, B., Chen, C., et al. (2022). The Role of Peat on Permafrost Thaw Based on Field Observations. CatenaCatena 208, 105772. doi:10.1016/j.catena.2021.105772

Erener, A. (2011). Remote Sensing of Vegetation Health for Reclaimed Areas of Seyitömer Open Cast Coal Mine. Int. J. Coal Geology. 86 (1), 20-26. doi:10. 1016/j.coal.2010.12.009

Gao, S.-h., He, R.-x., Jin, H.-j., Huang, Y.-d., Zhang, J.-m., and Luo, D.-l. (2017). Thermal Recovery Process of a Backfilled Open-Pit in Permafrost Area at the Gulian Strip Coal Mine in Northeast China. J. Mt. Sci. 14 (11), 2212-2229. doi:10.1007/s11629-017-4439-3

Gorbunov, A. P., and Seversky, E. V. (2001). "Influence of Coarsely Fragmental Deposits on Permafrost Formation," in Extended Abstracts, International Symposium on Mountain and Arid Land Permafrost (Ulaanbaatar: Urlah Erderm Publishing), 24-25.

Guo, D. X., Huang, Y. Z., Wang, J. C., Wang, B. L., Zeng, Z. G., and He, Y. X. (1989). Function of geologic structure in the formation of permafrost conditions in the Huola River Basin, North Da Hinggan Ling. J Glaciol Geocryol. 11 (3), 215-222.(in Chinese)

Han, F., Yu, W., Zhang, X., Yu, F., Yi, X., and Hu, D. (2019). Parameter Sensitivity Analyses of Influence on thermal Regime of Embankment in Permafrost Regions along the Qinghai-Tibet Engineering Corridor. Cold Regions Sci. Tech. 166 (10), 102817. doi:10.1016/j.coldregions.2019.102817

Harris, S. A. (1996). "Lower Mean Annual Ground Temperature beneath a Block Stream in the Kunlun Pass, Qinghai Province, China," in Proceedings, 5th Chinese Conference on Glaciology and Geocryology (Lanzhou: Gansu Culture Pres), 227-237.

Harris, S. A., and Pedersen, D. E. (1998). Thermal Regimes beneath Coarse Blocky Materials. Permafrost Periglac. Process. 9, 107-120. doi:10.1002/(sici)10991530(199804/06)9:2<107:aid-ppp277>3.0.co;2-g

He, R.-X., Jin, H.-J., Luo, D.-L., Li, X.-Y., Zhou, C.-F., Jia, N., et al. (2021b). Permafrost Changes in the Nanwenghe Wetlands Reserve on the Southern Slope of the Da Xing'anling-Yile'huli Mountains, Northeast China. Adv. Clim. Change Res. 12 (5), 696-709. doi:10.1016/j.accre.2021.06.007

He, R., Jia, N., Jin, H., Wang, H., and Li, X. (2021a). Experimental Study on thermal Conductivity of Organic-Rich Soils under Thawed and Frozen States. Geofluids 2021, 1-12. doi:10.1155/2021/7566669

He, R. X., Jin, H. J., Ma, F. T., Liu, F. C., and Xiao, D. H. (2015). Recent Progress in Studying Permafrost and Regions Environment in the Hola basin of north Greater Khingan Mountains. J. Glaciol Geocryol 37 (1), 109-117. (in Chinese).

Hildebrand, E. E. (1983). "Thaw Settlement and Ground Temperature Model for High Design in Permafrost," in Proceedings of the 4th International Conference on Permafrost (Washington DC: National Academy Press), 492-497. doi:10. 7522/j.issn.1000-0240.2015.0011

James, M., Lewkowicz, A. G., Smith, S. L., and Miceli, C. M. (2013). Multi-decadal Degradation and Persistence of Permafrost in the Alaska Highway Corridor, Northwest Canada. Environ. Res. Lett. 8 (4), 045013. doi:10.1088/1748-9326/8/ $4 / 045013$

Jin, H., Sun, G., Yu, S., Jin, R., and He, R. (2008). Symbiosis of Marshes and Permafrost in Da and Xiao Hinggan Mountains in Northeastern China. Chin. Geogr. Sci. 18 (1), 62-69. doi:10.1007/s11769-008-0062-0

Kelley, A. M., Epstein, H. E., and Walker, D. A. (2004). Role of vegetation and climate in permafrost active layer depth in arctic tundra of northern Alaska and Canada. Journal of Glaciology and Climatology 26, 269-274.

Lai, Y., Guo, H., and Dong, Y. (2009). Laboratory Investigation on the Cooling Effect of the Embankment with L-Shaped Thermosyphon and Crushed-Rock Revetment in Permafrost Regions. Cold Regions Sci. Tech. 58 (3), 143-150. doi:10.1016/j.coldregions.2009.05.002

Leng, Y. F. (2011). Experimental Research on Physical Mechanical Properties and Numerical Analysis on Temperature Field of Permafrost of China-Russia Oil Pipeline. Changchun: Jilin University. (in Chinese).

Li, J. P., Sheng, Y., Cao, W., and Qiu, Y. L. (2014). An Analysis of the Impact of Opencast Coal-Mining Pit Backfill on Permafrost Recovery. Hydrogeol Eng. Geol. 41 (4), 125-130. (in Chinese).
Liang, Z. F., Pan, Y. T., Feng, M. Y., Du, Y. S., Li, G. Y., and Ran, Z. (2018). Study on thermal Property of Coal Gangue. Coal Technol. 37 (10), 231-233. (in Chinese).

Luo, D., Jin, H., Jin, R., Yang, X., and Lü, L. (2014). Spatiotemporal Variations of Climate Warming in Northern Northeast China as Indicated by Freezing and Thawing Indices. Quat. Int. 349, 187-195. doi:10.1016/j.quaint.2014.06.064

Luo, D., Jin, H., Wu, Q., Bense, V. F., He, R., Ma, Q., et al. (2018). Thermal Regime of Warm-Dry Permafrost in Relation to Ground Surface Temperature in the Source Areas of the Yangtze and Yellow Rivers on the Qinghai-Tibet Plateau, SW China. Sci. Total Environ. 618, 1033-1045. doi:10.1016/j.scitotenv.2017.09.083

Luo, D., Liu, L., Jin, H., Wang, X., and Chen, F. (2020). Characteristics of Ground Surface Temperature at Chalaping in the Source Area of the Yellow River, Northeastern Tibetan Plateau. Agric. For. Meteorology 281, 107819. doi:10. 1016/j.agrformet.2019.107819

Moreno-de Las Heras, M., Merino-Martín, L., and Nicolau, J. M. (2009). Effect of Vegetation Cover on the Hydrology of Reclaimed Mining Soils under Mediterranean-Continental Climate. Catena 77 (1), 39-47. doi:10.1016/j. catena.2008.12.005

Nauta, A. L., Heijmans, M. M. P. D., Blok, D., Limpens, J., Elberling, B., Gallagher, A., et al. (2014). Permafrost Collapse after Shrub Removal Shifts Tundra Ecosystem to a Methane Source. Nat. Clim Change 5 (1), 67-70. doi:10. 1038/NCLIMATE2446

Pandey, B., Agrawal, M., and Singh, S. (2014). Coal Mining Activities Change Plant Community Structure Due to Air Pollution and Soil Degradation. Ecotoxicology 23 (8), 1474-1483. doi:10.1007/s10646-014-1289-4

Pei, W., Zhang, M., Lai, Y., Yan, Z., and Li, S. (2019). Evaluation of the Ground Heat Control Capacity of a Novel Air-L-Shaped TPCT-Ground (ALTG) Cooling System in Cold Regions. Energy 179, 655-668. doi:10.1016/j.energy. 2019.04.156

Peretrukhin, N. A., and Potaueva, T. V. (1983). "Laws Governing Interactions between railroad Roadbeds and Permafrost," in Proceedings of 4th international conference on Permafrost (Washington D C: National Academy Press), 984-987.

Qian, D., Yan, C., Xing, Z., and Xiu, L. (2017). Monitoring Coal Mine Changes and Their Impact on Landscape Patterns in an alpine Region: a Case Study of the Muli Coal Mine in the Qinghai-Tibet Plateau. Environ. Monit. Assess. 189 (11), 559. doi:10.1007/s10661-017-6284-9

Quinton, W. L., and Baltzer, J. L. (2013). The Active-Layer Hydrology of a Peat Plateau with Thawing Permafrost (Scotty Creek, Canada). Hydrogeol J. 21 (1), 201-220. doi:10.1007/s10040-012-0935-2

Quinton, W. L., Shirazi, T., Carey, S. K., and Pomeroy, J. W. (2005). Soil Water Storage and Active-Layer Development in a Sub-alpine Tundra Hillslope, Southern Yukon Territory, Canada. Permafrost Periglac. Process. 16 (4), 369-382. doi:10.1002/ppp.543

Romanovskij, N. N., and Turin, A. I. (1986). Kurums. Biul Peryglac. 31, 249-259. Serban, R. D., Serban, M., He, R. X., Jin, H. J., Li, X. Y., and Li, X. Y. (2021). 46-year (1973-2019) Permafrost Landscape Changes in the Ho'la Basin, Northeast China Using Machine Learning and Object-Oriented Classification. Remot Sens 13, 1910. doi:10.3390/rs13101910

Shur, Y. L., and Jorgenson, M. T. (2007). Patterns of Permafrost Formation and Degradation in Relation to Climate and Ecosystems. Permafrost and Periglacial Processes 18, 7-19. doi:10.1002/ppp.582

Smith, M. W., and Riseborough, D. W. (2002). Climate and the Limits of Permafrost: a Zonal Analysis. Permafrost Periglac. Process. 13, 1-15. doi:10. 1002/ppp.410

Tyrtikov, A. P. (1959). Perennially frozen ground and vegetation. In Fundamentals of Geocrylogy. Moscow: Academy of Science USSR, 399-421.

Wang, J. C., Guo, D. X., Huang, Y. Z., and Zeng, Z. G. (1989). A Study on Seasonally Thawed Layer in the Basin of Huola River in Northern Da Hinggan Ling. $J$ Glaciol Geocryol 11 (3), 203-214.

Wang, C. H. (1999). Freeze-Thaw Processes of Frozen Soils and Cold Regions Development and Construction in Northeast China. Beijing: Science Press (in Chinese).

Wang, G. X., Cheng, G. D., and Shen, Y. P. (2001). Research on Ecological Environmental Change in Changjiang-Yellow Rivers Source Regions and Their Integrated Protection. Lanzhou, China: Lanzhou University Press.

Wang, G. X., Yao, J. Z., Guo, Z. G., Wu, Q. B., and Wang, Y. B. (2004). Human Engineering Activities on Frozen Soil Ecosystem Change and its Effect on 
Railway Construction. Chin. Sci Bull 49 (15), 1556-1564. doi:10.1007/ bf03184309

Wang, J., Wang, H., Cao, Y., Bai, Z., and Qin, Q. (2016). Effects of Soil and Topographic Factors on Vegetation Restoration in Opencast Coal Mine Dumps Located in a Loess Area. Sci. Rep. 6, 22058. doi:10.1038/srep22058

Wang, T., Du, B., Li, C. C., Wang, H., Zhou, W., Wang, H., et al. (2021a). Ecological Environment Rehabilitation Management Model and Key Technologies in Plateau alpine Coal Mine. J. China Coal Soc. 46 (1), 230-244. (in Chinese).

Wang, T., Peng, E., Xia, L., Zhou, G., and Wang, J. (2021b). Uncertainties of thermal Boundaries and Soil Properties on Permafrost Table of Frozen Ground in Qinghai-Tibet Plateau. J. Rock Mech. Geotechnical Eng. 13 (3), 671-681. doi:10.1016/j.jrmge.2020.10.008

Xu, X. Z., Wang, J. C., and Zhang, L. X. (2001). Frozen Soil Physics. Beijing, China: Science Press, 86-91.

Yang, Z. W. (2018). Laboratory Investigation on thermal Conductivity of Typical Soil in the Northeast Inner Mongolia during Freezing and Thawing Processes. Hoh Hot, Inner Mongolia, China: Inner Mongolia University. (in Chinese).

Yanhu, M., Guoyu, L., Wei, M., Zhengmin, S., Zhiwei, Z., and Wang, F. (2020). Rapid Permafrost Thaw Induced by Heat Loss from a Buried Warm-Oil Pipeline and a New Mitigation Measure Combining Seasonal Air-Cooled Embankment and Pipe Insulation. Energy 203, 117919. doi:10.1016/j.energy. 2020.117919

Zhang, J., Rao, Y., Geng, Y., Fu, M., and Prishchepov, A. V. (2017). A Novel Understanding of Land Use Characteristics Caused by Mining Activities: A Case Study of Wu'an, China. Ecol. Eng. 99, 54-69. doi:10.1016/j.ecoleng.2016. 11.026

Zhang, L., Wang, J., Bai, Z., and Lv, C. (2015b). Effects of Vegetation on Runoff and Soil Erosion on Reclaimed Land in an Opencast Coal-Mine Dump in a Loess Area. Catena 128, 44-53. doi:10.1016/j.catena.2015.01.016

Zhang, M., Lai, Y., Zhang, J., and Sun, Z. (2011). Numerical Study on Cooling Characteristics of Two-phase Closed Thermosyphon Embankment in Permafrost Regions. Cold Regions Sci. Tech. 65 (2), 203-210. doi:10.1016/j. coldregions.2010.08.001
Zhang, M., Pei, W., Zhang, X., and Lu, J. (2015a). Lateral thermal Disturbance of Embankments in the Permafrost Regions of the Qinghai-Tibet Engineering Corridor. Nat. Hazards 78 (3), 2121-2142. doi:10.1007/s11069-015-1823-6

Zhang, Z. Q., Wu, Q. B., and Hou, M. T. (2021). Permafrost change in Northeast China in the 1950s-2010s. Advances in Climate Change Research 12 (1), 18-28. doi:10.1016/j.accre.2021.01.006

Zheng, H. L., and Ma, F. T. (2000). Effect of Opencast Mining on Permafrost Environment. Opencast Coal Min Technol 4, 14-16. (in Chinese)

Zhou, Y. W., Qiu, G. O., Guo, D. X., Cheng, G. D., and Li, S. D. (2000). Geocryology in China. Beijing: Science Press-450. (in Chinese).

Zhu, L. N. (1988). Study of the Adherent Layer on Different Types of Ground in Permafrost Regions on the Qinghai-Xizang Plateau. J. Glaciol Geocryol 10, 8-14. (in Chinese).

Conflict of Interest: The authors declare that the research was conducted in the absence of any commercial or financial relationships that could be construed as a potential conflict of interest.

The reviewer WP declared a shared affiliation with several of the authors, RH, YL, $\mathrm{HW}, \mathrm{YH}$, and DJ, to the handling editor at the time of review.

Publisher's Note: All claims expressed in this article are solely those of the authors and do not necessarily represent those of their affiliated organizations, or those of the publisher, the editors, and the reviewers. Any product that may be evaluated in this article, or claim that may be made by its manufacturer, is not guaranteed or endorsed by the publisher.

Copyright (C) $2022 \mathrm{He}$, Li, Jin, Wang, Jin, Zhu, Li, Huang, Jin and Ma. This is an open-access article distributed under the terms of the Creative Commons Attribution License (CC BY). The use, distribution or reproduction in other forums is permitted, provided the original author(s) and the copyright owner(s) are credited and that the original publication in this journal is cited, in accordance with accepted academic practice. No use, distribution or reproduction is permitted which does not comply with these terms. 